Recent Advances in Experimental Mechanics 


\section{Recent Advances in Experimental Mechanics}

In Honor of Isaac M. Daniel

Edited by

EMMANUEL E. GDOUTOS

Northwestern University,

Evanston, IL, U.S.A. 
eBook ISBN: $\quad$ 0-306-48410-2

Print ISBN: $\quad$ 1-4020-0683-7

(C)2004 Kluwer Academic Publishers

New York, Boston, Dordrecht, London, Moscow

Print @2002 Kluwer Academic Publishers

Dordrecht

All rights reserved

No part of this eBook may be reproduced or transmitted in any form or by any means, electronic, mechanical, recording, or otherwise, without written consent from the Publisher

Created in the United States of America

Visit Kluwer Online at:

http://kluweronline.com

and Kluwer's eBookstore at:

http://ebooks.kluweronline.com 


\section{Editor's Preface}

This book contains 71 papers presented at the symposium on "Recent Advances in Experimental Mechanics" which was organized in honor of Professor Isaac M. Daniel. The symposium took place at Virginia Polytechnic Institute and State University on June 23-28, 2002, in conjunction with the $14^{\text {th }}$ US National Congress of Applied Mechanics. The book is a tribute to Isaac Daniel, a pioneer of experimental mechanics and composite materials, in recognition of his continuous, original, diversified and outstanding contributions for half a century.

The book consists of invited papers written by leading experts in the field. It contains original contributions concerning the latest developments in experimental mechanics. It covers a wide range of subjects, including optical methods of stress analysis (photoelasticity, moiré, etc.), composite materials, sandwich construction, fracture mechanics, fatigue and damage, nondestructive evaluation, dynamic problems, fiber optic sensors, speckle metrology, digital image processing, nanotechnology, neutron diffraction and synchrotron radiation methods.

The papers are arranged in the following nine sections: Mechanical characterization of material behavior, composite materials, fracture and fatigue, optical methods, nondestructive evaluation, neutron diffraction and synchrotron radiation methods, hybrid methods, composite structures, and structural testing and analysis.

The first section on mechanical characterization and material behavior contains eight papers dealing with dynamic tests using Hopkinson bar techniques, gradient theory of micro-scale plasticity, time-dependent materials, foam materials, carbon nanotubes and nanostructured coatings. The second section on composite materials contains nine papers dealing with state variables, properties at high strain rates, metal matrix composites, particulate composites, hygric characterization, pneumatic behavior, compressive strength, interfacial strength and toughness, and residual strength after damage due to impact and erosion. The third section on fracture and fatigue contains ten papers dealing with a probabilistic model of fatigue, damage tolerance analysis, crack growth, failure initiation, crack paths in adhesive bonds, failure of spot welds, and dynamic and intersonic crack growth. The fourth section on optical methods contains seven papers dealing with moiré interferometry, optical fiber sensors, displacement measurements based on optoelectronics and photogrammetry, fracture processes using digital image correlation, determination of fringe order using different wavelengths, and heart mechanics problems by means of speckle metrology. The fifth section on nondestructive evaluation contains eight papers dealing with acoustic microscopy, acoustography, waves in elastic materials, shearography, laser-ultrasonics, scattering of flexural waves, and ultrasonic applications. The sixth section on neutron diffraction 
and synchrotron radiation methods contains eight papers dealing with neutron diffraction techniques for strain scanning and measurement of residual stresses and synchrotron radiation analyses. The seventh section on hybrid methods contains eight papers dealing with combined numerical and experimental methods. The eighth section on composite structures contains six papers dealing with composite materials and sandwich structures. Finally, the ninth section on structural testing and analysis contains seven papers dealing with bridges, aircraft, stereolithography, sheet metal forming, and adhesive joints.

I consider it an honor and privilege to have had the opportunity to edit this volume. I wish to thank very sincerely the authors who have contributed to this volume and all those who participated in the symposium on "Recent Advances in Experimental Mechanics" to honor Isaac M. Daniel, a hero of experimental mechanics, a warmhearted individual, a loyal friend, a colleague, whose work and ideas have and will be indelibly imprinted on the pages of solid mechanics history. Special thanks are due to my friend Dr. A. Youtsos of Joint Research Center of European Union at Petten, The Netherlands, who organized a special session on "Neutron diffraction and synchrotron radiation methods."

My deep appreciation and thanks go to Mrs Yolande Mallian for her many months of hard work and devotion and her dedicated. and competent support in the timely and meticulous editing of this work. Finally, a special word of thanks goes to Dr. Arno Schouwerburg of Kluwer Academic Publishers for his interest in publishing this work and his kind collaboration and support.

March 2002

Evanston, IL USA
Emmanuel E. Gdoutos

Editor 


\section{Table of Contents}

Editor's Preface $\quad$ V

Biography of Isaac M. Daniel $\quad$ XV

List of Publications by Isaac M. Daniel xxi

List of Contributors $\quad$ xlv

\section{Mechanical Behavior of Materials}

Hopkinson Techniques for Dynamic Triaxial Compression Tests

J. Rome, J. Isaacs and S. Nemat-Nasser

Asymptotic Scaling of Gradient Theory of Micro-Scale Plasticity of Metals

Z. P. Bãzant

The Role of Pressure in the Behavior of Time-Dependent Materials

T. Prodan and I. Emri

High Strain Rate Testing of Sandwich Core Materials

M. Vural and G. Ravichandran

Development of a Shear Test for Low Modulus Foam Materials

A. K. Roy and J. D. Camping

Indentation of a PVC Cellular Foam

E. E. Gdoutos and J. L. A bot

Nanomanipulation and Characterization of Individual Carbon Nanotubes

R. S. Ruoff, M.-F. Yu and H. Rohrs

Quasi-Static and Dynamic Torsion Testing of Ceramic Micro and

Nano-Structured Coatings Using Speckle Photography

F. Barthelat, K. Malukhin and H. Espinosa

\section{Composite Materials}

Measured Response: State Variables for Composite Materials

K. Reifsnider and M. Pastor

On the Modeling of the Mechanical Properties of Composite

Materials at High Strain Rates

J. R. Vinson and S. Xiao 
Damage Quantification in Metal Matrix Composites

G. Z. Voyiadjis, A. R. Venson, and R. K. Abu-Alrub

Study of Damage in Particulate Composites

C. A. Sciammarella and F. M. Sciammarella

Hygric Characterization of Composite Laminates

S.-C. Wooh and C.-L Tsai

Pneumatic Behavior of Composite Materials

C.-L. Tsai and Y.-S. Tsai

The Effect of Specimen Size on the Compressive Strength of

Carbon Fibre-Epoxy Laminates

C. Soutis and J. Lee

Interfacial Strength and Toughness Characterization Using a

Novel Test Specimen

G. P. Tandon, R. Y. Kim and V. T. Bechel

A Model for the Accurate Prediction of the Residual Strength

after Damage Due to Impact and Erosion of FRPs

G. C. Papanicolaou, G. Samoilis, S. Giannis,

N.-M. Barkoula and J. Karger-Kocsis

\section{Fracture and Fatigue}

The Origin and Inception of Fatigue in Steel - A Probabilistic Model

S. A. Guralnick and J. Mohammadi

Fatigue Damage Tolerant Analysis Using the Fatigue Damage Map

C. A. Rodopoulos andJ. R. Yates

Crack Growth Behavior and SIF's as Observed by Optical Methods

C. W. Smith

A Model for Failure Initiation in Ductile Materials

J. Zuo, M. A. Sutton andX. Deng

Crack Paths in Adhesive Bonds

L. Banks-Sills and J. Schwartz.

Experimental Determination of Fracture Parameters for Predicting

Crack Growth in Viscoelastic Polymers

D. H. Allen and J. J. Williams

Failure of Spot Weld: A Competition Between Crack Mechanics

and Plastic Collapse

Y. J. Chao 
Investigating the Effects of Specimen Thickness and Pressure on the

Crack Growth Behavior of a Particulate Composite Material

C. T. Liu

Dynamic Fracture Experiments Using Point Impact

D. Rittel

Experimental and Numerical Investigation of Shear-Dominated Intersonic

Crack Growth and Friction in Unidirectional Composites

A. J. Rosakis, C. Yu, M. Ortiz, D. Coker and A. Pandolfi

\section{Optical Methods}

Moiré Interferometry - Past, Present and Future

D. Post

Optical Fibre Bragg Grating Sensors in Experimental Mechanics of

Composite Laminated Plates

J. Botsis, F. Bosia, M. Facchini, Th. Gmür

Optoelectronic Displacement Measurement Method for Rotating Disks

C. E. Bakis, B. J. Haldeman andR. P. Emerson

Deformation Measurement of Sheet Metal Forming Using Photogrammetry

K. Andresen

Fracture Processes of Quasi-Brittle Materials Studied with Digital

Image Correlation

J. S. Lawler and S. P. Shah

On the Use of Different Wavelengths to Digitally Determine

the Isochromatic Fringe Order

T. Y. Chen, Y. C. Chou, H. L. Lee andS. H. Tsao

The Application of Speckle Metrology to Heart Mechanics

G. R. Gaudette, E. U. Azeloglu, J. Todaro, L. Keene,

I. B. Krukenkamp and F. P. Chiang

\section{Non-Destructive Evaluation}

Line Focus Acoustic Microscopy for Thin-Film Measurements

Z. Guo and J. D. Achenbach

Recent Advances in Acoustography-Based NDE

J. S. Sandhu and H. Wang

Experimental Limitations to Guided Wave Generation in Elastic Materials

D. A. Sotiropoulos and E. Babatsouli 
Nondestructive Testing Using Shearography

M.Y.Y. Hung

Theoretical and Experimental Study of Laser-Ultrasonic Signal

Characteristics Enhanced by Wetting the Surface

S.-C. Wooh

Defect Detection by the Scattering Analysis of Flexural Waves

P. Fromme and M. B. Sayir

Evaluation of Fiber Waviness in Thick Composites by Ultrasonic Test

H.-J. Chun

Development of a Dry-Contact Ultrasonic Technique and its

Application to NDE of IC Packages

H. Tohmyoh and M. Saka

\section{Neutron Diffraction and Synchrotron Radiation Methods}

High-Resolution Neutron Diffraction Techniques for Strain Scanning

P. Mikula, M. Vrana, P. Lukas and V. Wagner

Draft Standard for the Measurement of Residual Stresses by

Neutron Diffraction

G. A. Webster, A. G. Youtsos, C. Ohms and R. C. Wimpory

Microstresses Determined by Neutron Diffraction and

Self-Consistent Model

A. Baczmanski, C. Braham, R. Levy-Tubiana, A. Lodini and K. Wierzbanowski

Residual Stress Measurements at the Metal/Ceramic Interface

Using Modelling of Neutron Diffraction Spectrometer

A. Carrado, J.-M. Sprauel, L. Barrallier and A. Lodini

Elastoplastic Deformation of Two Phase Steels Studied by Neutron

Diffraction and Self-Consistent Modelling

M. R. Daymond, H. G. Priesmeyer and A. M. Korsunsky

Residual Stresses and Elastic Constants in Thermal Deposits

T. Gnäupel-Herold, H. J. Prask and F. S. Biancaniello

Neutron Diffraction Assisted Residual Stress Analysis in

Welded Structures

C. Ohms andA. G. Youtsos 
Synchrotron Radiation In-Situ Analyses of AA $6061+\mathrm{AL}_{2} \mathrm{O}_{3}$ During Tensile

Deformation at Ambient and Elevated Temperature

A. Pyzalla, B. Reetz, A. Jacques, J.-P. Feiereisen, O. Ferry and

T. Buslaps

\section{Hybrid Methods}

Reflections on the Importance of Experimental Results to all Mechanicists,

Especially Theoreticians

$R$. M. Jones

Mixed Numerical-Experimental Techniques : Past, Present and Future

A. H. Cardon, H. Sol, W. P. De Wilde, J. De Visscher,

$K$. Hoes and D. Dinescu

A Moiré-FE Method for Internal CTOA Determination

J. H. Jackson and A. S. Kobayashi

Patterns of Modern Experimental Mechanics

J. T. Pindera

Inverse Methods in Experimental Mechanics

J. F. Doyle

Complex Stiffness Identification by Inverse Methods

H. Sol and W. P. De Wilde

Considerations of a Flutter Prediction Methodology Using a

Combined Analytical-Experimental Procedure

P. Marzocca, L. Librescu and W. A. Silva

Displacement-Based Smoothing Hybrid Finite-Element Representation for Stress Analyzing Perforated Composites

K. Y. He and R. E. Rowlands

\section{Composite Structures}

Future Experimental Methods Needed to Verify Composite

Life-Cycle Simulations

C. C. Chamis and L. Minnetyan

Experimental Observations on the Delamination Behavior in Composite Structures

G. A. Kardomateas, V. La Saponara and G. J. Simitses 
Direct Identification of Elastic Properties of Composite Structures -

A Wave-Controlled Impact Approach

$$
\text { S. Abrate }
$$

Static Behaviour of Pre-Stressed Polymer Composite Sandwich Beams

R. A. W. Mines, Q. M. Li, R. S. Birch, R. Rigby,

M. Al-Khalil and A. Tanner

On Debond Failure of Foam Core Sandwich

683

L. A. Carlsson

Core Crush Mechanisms and Solutions in the Manufacturing of

Sandwich Structures

H. M. Hsiao, S. M. Lee and R. A. Buyny

Displacement Fields Around a Circular Hole in Composite Laminates

S. M. Chern and M. E. Tuttle

\section{Structural Testing and Analysis}

Recent Advances in Long-Term Monitoring of Bridges

J. R. Casas

An Experimental Mechanics Approach to Structural Health

Monitoring for Civil Aircraft

E. W. O'Brien

Smart Structures Application to Airworthiness and Repair

R. Jones, I. H. McKenzie, S. Galea and S. Pitt

Experimental Investigation of Shrinkage Strains in Multilayered

Stereolithography Parts

D. E. Karalekas

Suppression of Dimpling In Sheet Metal Parts Formed on

Discrete Tooling

R. C. Schwarz, J. Nardiello andJ. M. Papazian

Effect of Loading Rate and Geometry Variation on the Dynamic

Shear Strength of Adhesive Lap Joints

V. Srivastava, V. Parameswaran, A. Shukla and D. Morgan

Author Index

Subject Index 


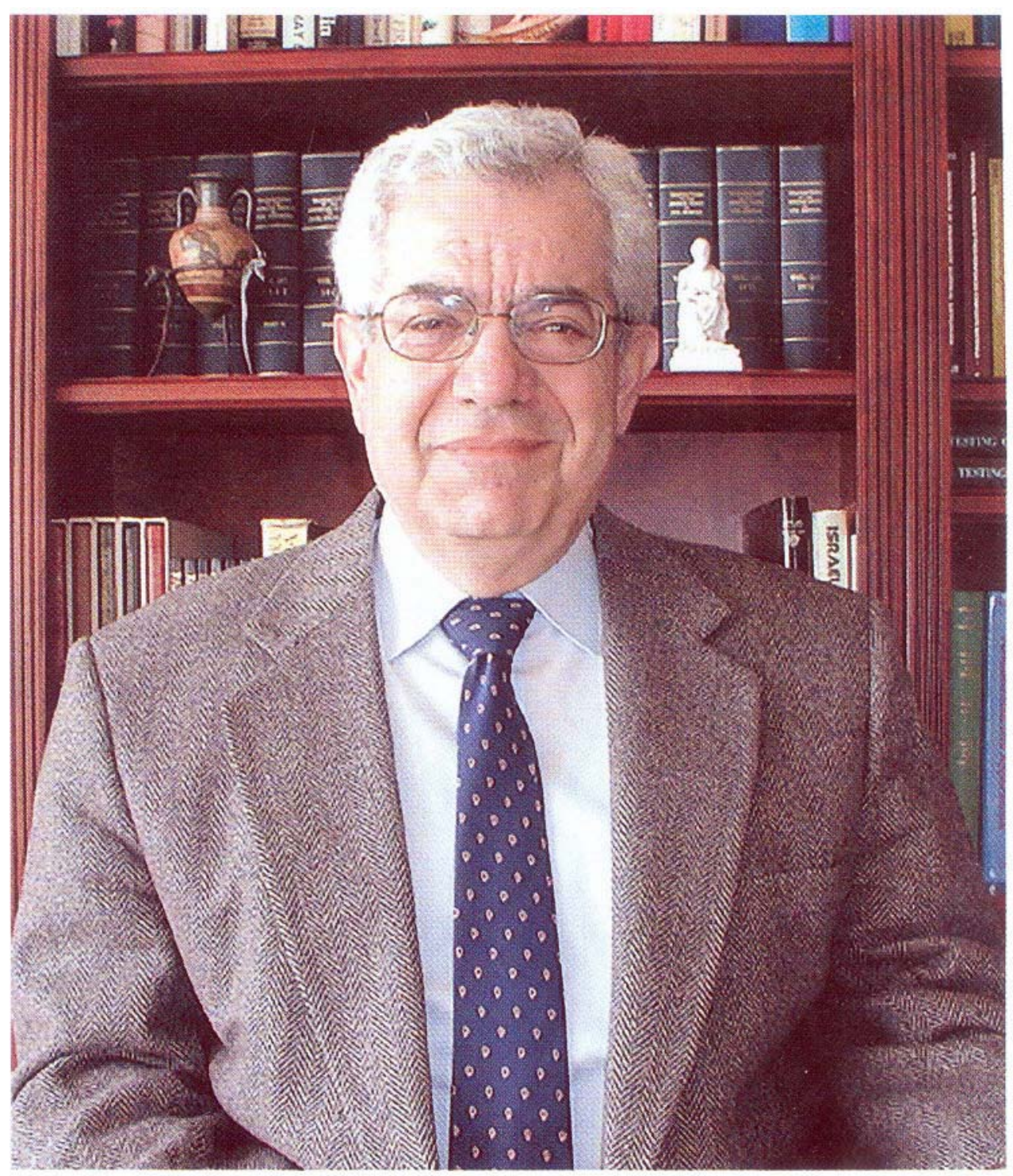

ISAAC M. DANIEL 


\section{Biography of Isaac M. Daniel}

Isaac M. Daniel was born on October 7, 1933 in Thessaloniki (Salonica), Greece, second of four children of Mordochai Daniel and Bella (Modiano) Daniel. Thessaloniki, the second largest city in Greece, is an ancient city named by Alexander the Great for his sister. It is also near Aristotle's birthplace. His family, for the most part, traces its origins to Spain from where they were expelled in 1492 for religious reasons, although it also has roots in a community that lived in the area for over 2000 years. His father was born and raised in the nearby town of Veria (Veroia) also an ancient city. His mother's family came from Livorno, Italy and is distantly related to the painter Amedeo Modigliani.

Thessaloniki, originally the center of Alexander's Macedonia became successively part of the Roman, Byzantine and Ottoman empires until 1912 when it was incorporated in Greece. Sometimes when talking about his family's background, Isaac says that his mother was born in Turkey, raised in Greece as an Italian citizen, attended an Italian school where she learned French, but at home she spoke Ladino (a medieval Spanish dialect with admixtures of Hebrew, Portuguese, Italian, Greek, French and Turkish).

Before the Second World War, Isaac's family moved to Veria (about 45 miles west of Thessaloniki) which at the time had a population of around 15,000. He entered the local Jewish school and attended the Synagogue that the apostle Paul visited some 2000 years ago. Isaac's father was a cabinet maker and occasionally worked as a grain dealer. His peaceful life came to a halt with the German invasion and its consequences. He still remembers all the horrible details of that period.

The roundup of the Jewish community came suddenly, but his family miraculously escaped and hid in their basement. They lived in that basement, just like Ann Frank, for about a month until they were found out, arrested and put in the Baron Hirsch transit camp in Thessaloniki. They were scheduled to be shipped within days to the death camps of Auschwitz, when another miracle occurred. They were put on somebody's list, the list of Guelfo Zamboni, the Italian consul in Thessaloniki. Through his intervention, 280 inmates, with direct or remote connection to Italian citizenship, out of more than 55,000 who passed through that camp, were released and taken to Athens which was then under Italian control. After Italy surrendered to the allies, life in Athens during the remaining war years became turbulent and full of dangerous adventures and more miraculous and narrow escapes. After the liberation on October 12, 1944, the troubles were not completely over, as they were caught in the middle of a brief but bloody civil war. Finally, they managed to return to their home in Veria and tried to start rebuilding their broken lives. They had lost over fifty of their relatives and most of their friends.

In 1945 Isaac Daniel enrolled in one of the public schools in Veria and then entered, after an entrance examination, the Gymnasium (High School). He has very 
good memories of his high school years. He was very popular and had many friends. The school followed a classical curriculum which included among others, six years of ancient Greek, and four years of Latin and French. In the senior year the students put on a play and they raised enough funds for a class trip to southern Greece and the islands. It was Isaac's first and only attempt as a playright. He had no favorite or less favorite subjects. He was equally at ease with Math and Science as with history and literature. He wrote poetry and had one poem published. He was selected to give the valedictory address at his graduation. He was told that a couple of his teachers had tears in their eyes during the speech.

Graduation from high school was the end of a care-free period and the beginning of a new phase of career planning and preparation. The high school principal who counseled all the graduating students individually told Isaac that he had no special advice to give him, that he would do well in whatever career he followed. It was a choice among Literature, Medicine and Engineering. He chose the latter because it seemed to be the most challenging at the time. The entrance exams for the National Technical University in Athens (the only technical school in the country at that time) were the toughest of all. The best graduating students from all high schools would take a year off and enter a preparatory school before attempting the entrance exams. Upon graduation from high school Isaac Daniel attended a preparatory school for less than a month and he spent the rest of the summer studying by himself. He took the exams in the fall and it was one of the greatest days of his life when he heard that he was successful.

He entered the School of Civil Engineering at the National Technical University (Metsovion Polytechnion). They had classes from 5 to 8 hours a day, six days a week. He finished two years and had enrolled for the third year when he immigrated with his family to the United States.

The family settled in Chicago in 1955 and Isaac transferred to the Illinois Institute of Technology. It was a bit of a cultural shock. He was more advanced in technical and math subjects, but he had to take English literature and other liberal arts courses. He was a straight A student and graduated with distinction, first in his class as well as the entire Engineering Division of IIT in 1957. He received a Fellowship from the Chicago Bridge and Iron Co. and entered graduate school at IIT.

IIT had an illustrious tradition in Mechanics with names like Enrico Volterra, Bill Ramberg, Eli Sternberg, Daniel Drucker and others associated with it before Isaac came. He had great teachers like August Durelli, Max Frocht, Lloyd Donnell and Phil Hodge. Durelli was his first mentor who introduced him to the field of Experimental Mechanics. Durelli was a scientist, philosopher and humanist. Frocht taught him precision and quality of presentation, especially in the case of photoelastic fringe patterns. Donnell impressed him by demonstrating the thought processes and approximations involved in developing complex relations. Hodge was clear and methodical in his lectures on continuum mechanics and plasticity. In addition to the technical knowledge, he learned one wise life guideline: "what is not worth doing is not worth doing well."

As he was finishing his Master's degree studies, Durelli offered Isaac a job at the Armour Research Foundation (later IIT Research Institute) the research affiliate of IIT, where he became deeply involved in Experimental Stress Analysis. At that time, the 
late 50's and early 60's, the IIT campus was a hotbed of activity in experimental stress analysis. Albert Kobayashi and Pericles Theocaris had both worked in Durelli's laboratory. He was fortunate to have supervisors and colleagues like Jim Dally, Bill Riley, Cesar Sciammarella, Vince Parks, Bob Rowlands and Ted Liber. The biggest compliment that Durelli paid Isaac, when he ran the first dynamic photoelasticity test and showed him the results, was a quotation from El Cid: "leurs coups d'essai veulent des coups de maître" (their trial strokes are master strokes). His first technical presentation, based on his Master's thesis, was at the ASME meeting in New Orleans in 1960.

The work at Armour (IITRI) was exciting. Isaac Daniel worked on stress analysis problems using photoelastic, moiré and strain gage methods. He worked on fracture of brittle materials and published work on fracture probabilities with N. A. Weil. He worked on creep of rubberlike materials and was impressed to verify experimentally that the equilibrium modulus of these materials is proportional to the absolute temperature as predicted. He became interested in viscoelasticity and this led him to write a proposal to the Air Force for the development of dynamic photoviscoelasticity and application to the study of stress waves in earth media. This led him to his Ph.D. research which he did while working full-time at IITRI. The research was reviewed by a committee including K. H. Chu, Jim Dally, Phil Hodge and Frank Essenburg of IIT and IITRI. In the course of this research he received valuable advice from Y. H. Pao of Cornell who was visiting at IITRI for one summer. He developed a theory of photothermoviscoelasticity and applied it to wave propagation problems. In 1964, Isaac received his Ph.D. He continued research in the areas of wave propagation and rock mechanics and started applying experimental stress analysis methods to the emerging technology of composite materials. Initially, he studied the micromechanics of composites by means of photoelasticity.

In the middle 60's there was a government thrust to develop advanced composites. Texaco had developed a new boron prepreg tape, which was $1 / 8$ in. wide. Isaac Daniel and his co-workers made their first advanced composite sample from this tape, the size of a postage stamp. The government announced a large program and encouraged the collaboration of universities, research institutes and industry. Isaac's director at IITRI wrapped the postage stamp sized specimen in his wallet and they both flew to Fort Worth to meet with General Dynamics. At a high level technical meeting they asked Isaac how much experience he had with advanced composites. Before he had a chance to say "not much" his boss kicked him under the table and said that they had expertise in fabricating composites and showed them the specimen. The General Dynamics people were impressed. It was proposed then that the first application be a flat part, namely the horizontal stabilizer of the F-111.

Isaac Daniel was appointed manager of the Experimental Stress Analysis Section at IITRI, a position previously held by Durelli and Riley. It was a heady time for research in composites and the funding was lavish. There were no established testing procedures for composites and the common practice was to adopt the same methods used for metals. For example, tensile testing was done by ultrasonically machining a narrowed section in a boron/epoxy coupon. This process, besides being very expensive and time consuming, did not work. It was then that Isaac tried a straight-sided coupon tabbed with glass/epoxy tapered tabs, a method that has become an ASTM standard. In the 
following years his work with composites expanded in all directions including processing, development of test methods, micromechanics, material characterization, special test methods (torsion, impact, creep/relaxation, fracture toughness, hygrothermal effects, high rate testing, multi-axial testing, fatigue), stress and failure analysis (stress concentrations, joints, warpage), damage mechanics and nondestructive evaluation.

In the early 70's he worked with Bob Rowlands and Jim Whiteside of Grumman on the effects of stress concentrations in composite panels. They applied birefringent coatings and moiré techniques to study the deformation and failure around holes. This work was extended later to investigations of size effects and biaxial loading. He built a new biaxial testing system for flat plates. He had a chance to work on speckle interferometry with Mike Hung during his brief sojourn in his group at IITRI. In the 70's he also worked with Ted Liber on developing an embedded strain gage technique for determination of curing residual stresses, biaxial testing using tubular specimens, high strain rate testing and nondestructive evaluation of composites. He developed and built a fully controlled test system for multiaxial testing of thin wall tubular specimens. He also developed a new method for testing composites at very high strain rates using thin ring specimens subjected to an internal pressure pulse produced by an explosive inside a liquid container. This method did not have the limitations of other methods using test coupons such as the Hopkinson bar method, where stress wave propagation over the length of the specimen produces a nonuniform stress distribution. In the case of the thin ring specimen under internal pressure there are no end effects and the relevant dimension is the thickness of the ring. He also found out that they could determine dynamic compressive properties by loading thin wall cylinders under external pressure without producing buckling, if the pressure were applied at a sufficiently high rate.

Isaac Daniel received two best paper awards from the Society for Experimental Stress Analysis (SESA and later SEM). He became Fellow of SESA in 1981 and was invited to be the keynote speaker at the 7th International Conference on Experimental Mechanics in 1982 in Haifa. In the same year he coauthored with Jim Whitney and Byron Pipes a monograph on Experimental Mechanics of Composites.

In January 1982 he was invited to join IIT as Professor and Director of the Experimental Stress Analysis Laboratory (later Mechanics of Materials Laboratory). The first grant he received at IIT was from ONR (Yapa Rajapakse) which has continued its support to date. During this period he worked on damage mechanics of composites, including damage characterization, evolution and accumulation, accelerated testing and life prediction; dynamic fracture toughness, and nondestructive evaluation of composites.

In 1984 he received the B. J. Lazan Award for outstanding original contributions in Experimental Mechanics. In the same year he spent the summer in Poitiers, France, as a visiting Professor at the invitation of Professor Alexis Lagarde, and gave several seminars on composites.

In early 1986 he was invited to give a seminar at Northwestern University. During lunch, Toshio Mura, in his inimitable fashion, said to him: "After you join us in the fall, we will write a proposal together on solitons." That was the first hint he got of the offer from Northwestern that came later and he couldn't refuse. He joined Northwestern and he wrote the proposal with Toshio Mura to NSF. It received two "excellent" and one 
"very good" rating, but it was not funded. He continued the work in damage mechanics and damage evolution in composites. This included development of models for stiffness and strength degradation and closed form expressions for constitutive behavior of cracked composite laminates with students Jae-Won Lee and Cho-Liang Tsai, now at Samsung Company in Korea and Yun Lin University in Taiwan, respectively. With Tsai he developed a unique method for determining all three shear moduli of an orthotropic composite. He developed advanced ultrasonic and acoustic emission techniques for flaw and damage detection and characterization with his student ShiChang Wooh, now Professor at MIT. This work included ultrasonic methods for threedimensional imaging of internal damage, detecting porosity and for determination of elastic properties of composites. He worked with Tao-Ming Wang (now at Illinois Tool Works) on control of residual stresses and warpage in circuit boards, a problem of great interest in electronic packaging. One result of this work was a method for measuring the chemical cure shrinkage in composite laminates.

A multi-year program, started in the late 80's, was the investigation of constitutive behavior of metal matrix composites sponsored by NASA-Lewis (Chris Chamis). He worked with his students Dimitri Karalekas and Heoung-Jae Chun, now Professors at the University of Piraeus, Greece and Yonsei University in Korea, respectively. They did a very extensive characterization of elastic and viscoelastic behavior of metal matrix composites at ambient and elevated temperatures.

Starting in the late 80's and continuing into the 90's he embarked on the study of micromechanics of failure and constitutive behavior of ceramic matrix composites with his students Jae-Won Lee, George Anastasopoulos and Jyi-Jiin Luo. Based on real time observations of microscopic failure modes and acoustic emission output, they proposed analytical constitutive models describing material response up to failure. The investigation was extended to elevated temperatures and determination of residual stresses. He worked with his former student and now research associate Jyi-Jiin Luo on the development of an analytical model and a general theory for characterizing deformation of damaged composites.

One of the most satisfying activities for Isaac Daniel in the early 90's was writing the textbook "Engineering Mechanics of Composite Materials," with Ori Ishai of the Technion in Israel. The book has been very well received by the community and is widely used as a textbook throughout the world. He is currently working with Ishai on the second edition.

In the early 90's the composites thrust of ONR shifted to the compressive behavior of thick composites. With his student Hao-Ming Hsiao he developed methods for manufacturing thick composites of uniform quality and a new method for compressive testing of such composites using a specially designed fixture (NU fixture). They studied and recorded the failure mechanisms of kink band formation and its propagation. They investigated experimentally and modeled the behavior, both linear and nonlinear, of thick composites with fiber waviness. The above studies were followed by extensive investigations of the effects of high strain rate on the stress-strain behavior and properties of composites under tension, compression and shear.

This work was followed by research in the area of composite sandwich structures with the help of Emmanuel Gdoutos, visiting Professor from Democritus University of Thrace, Greece, and former student and now research associate Jandro Abot. They 
developed methods for fabrication and testing of sandwich structures statically and under impact and studied experimentally and analytically the various failure modes and criteria for their occurrence.

A major expansion of his activity in composites occurred at the end of 1997 when Professor Daniel became Director of the new Center for Intelligent Processing of Composites. The objective of this center is to develop a comprehensive, commercially viable approach for fabrication of affordable, functional and reliable composite structures. This is an interdisciplinary program conducted by a team including University faculty, industrial firms and the government. Contributions of Daniel's group in this Center include the design and fabrication of an innovative computer controlled system for resin transfer molding (RTM); new methods for characterizing reinforcement preforms; flow and cure models; and a new noninvasive approach for online quality control of reinforcement quality, a method of great commercial potential.

Isaac Daniel received several recognitions and awards in the 90's. He became Fellow of the American Academy of Mechanics (1994); was invited to be a keynote speaker at the International Conference on Composites Engineering in New Orleans (1995); received the Distinguished Research Award of the American Society for Composites (1996); was elected Chairman of the Theoretical and Applied Mechanics program at Northwestern University (1996); received the William M. Murray Medal of the Society for Experimental Mechanics and gave the associated prestigious lecture to the society (1998); he was appointed the Walter P. Murphy Professor of Civil and Mechanical Engineering at Northwestern University (1998); became Fellow of the American Society of Mechanical Engineers (1999); received the Professional Achievement Award from his alma mater, the Illinois Institute of Technology (1999).

Besides all the research and professional activities, Isaac leads a busy and happy family life. His wife Elaine Krule Daniel of Chicago shares many interests with him. She studied at the Sorbonne and the University of Illinois. Elaine is a polyglot with degrees in French and teaching English as a second language and has taught at the University of Illinois in Champaign-Urbana and the University of Louisville in Kentucky. She is also a gourmet cook and a quilter. They have three children, Belinda, 13, Rebecca, 11, and Max 9. Isaac spends a lot of time with his family taking them along on trips to summer conferences in the United States and abroad. He attends and participates in the children's activities, such as concerts and Boy Scout projects. He is active in community affairs, reads, travels and is interested in photography. He has a sense of humor which Elaine appreciates by laughing at his jokes even when she hears them for the fifth time. He shares a special interest with Elaine in linguistics and their dream is to write a Ladino-English dictionary.

Isaac was very close to his father and mother who passed away in 1993 at the ages of 94 and 86. His older brother, Aaron, is an architect living in California. When he lived in Chicago he contributed to the design of the Sears Tower and the Civic Center plaza. His sister, Sarah Spector, has a degree in nutrition and lives in Chicago. His younger brother Sam, works for Motorola on artificial intelligence and lives in Arizona.

Isaac Daniel has no immediate plans for retirement. People say that his children keep him young and active. He hopes to continue working and help his children with their education and, maybe, have them in his class. 


\section{List of Publications by Isaac M. Daniel}

\section{Books}

Experimental Mechanics of Fiber Reinforced Composite Materials, with James M. Whitney and R. Byron Pipes, Society for Experimental Mechanics, Monograph No. 4, SEM, Bethel, CT, 1982; Second Edition, 1985.

Composite Materials: Testing and Design (Sixth Conference), ASTM STP 787, I. M. Daniel, ed., American Society for Testing and Materials, 1982.

Engineering Mechanics of Composite Materials, with Ori Ishai, Oxford University Press, New York, 1994.

\section{Contributions to Books}

"Theoretical Stress Analysis," in Testing of Polymers, Vol. 4, ed. by W. E. Brown, Interscience Publishers, New York, 1969, pp. 297-378.

"Photoelastic Investigation of Composites," in Composite Materials, Vol. 2, "Mechanics of Composite Materials," (Vol. ed. G. P. Sendeckyj, Series Eds. L. J. Broutman and R. H. Krock), Academic Press, 1974.

"Photoelastic Studies of Mechanics of Composites," in Progress in Experimental Mechanics, Durelli Anniversary Volume, Catholic University of America, 1975.

"Methods of Testing Composite Materials," Chapter in Fracture Mechanics and Methods of Testing, Vol. ed. by G. C. Sih and A. M. Skudra in Series Handbook of Fibrous Composites, ed. by A. Kelly and Y. N. Rabotnov, North Holland Publishing Co., Amsterdam, 1985.

"Dynamic Photoelasticity," in Photoelasticity in Engineering Practice, ed. by S. A. Paipetis and G. S. Hollister, Elsevier Applied Sci. Publishers, London and New York, 1985.

"Composites-Testing," in Encyclopedia of Polymer Science and Engineering, John Wiley and Sons, 1985.

"Composite Materials," in Handbook on Experimental Mechanics, 2nd ed., VCH Publishers, New York, 1993. 
"Nondestructive Evaluation of Composite Materials," Flight-Vehicle Materials, Structures and Dynamics, Vol. 4, pp. 313-342, Tribological Materials and NDE, ed. by R. L. Fusaro and J. D. Achenbach, Series eds., A. K. Noor and S. L. Venneri, The Amer. Soc. of Mech. Eng., New York, 1992.

"Testing, Mechanical Characterization," Encyclopedia of Composites, Vol. 5, S. M. Lee, ed, VCH Publishers, New York, 1991.

\section{Articles in Journals and Proceedings}

1. "Stress Analysis of a Cylindrical Shell Ring Stiffener," ASME Paper No. 60-PET26, September 1960.

2. "Structural Model Analysis by Means of Moiré Fringes," with A. J. Durelli, Proceedings of ASCE, Journal of Structural Division, ST 12, Vol. 86, No. 2693, December 1960, pp. 93-102.

3. "Photoelastic Investigation of Residual Stresses in Glass-Plastic Composites," with A. J. Durelli, Proceedings of 16th Conference of Reinforced Plastics Division, Society of Plastics Industry, Section 19-A, February 1961.

4. "Photothermoelastic Analysis of Bonded Propellant Grains," with A. J. Durelli, Experimental Mechanics, Vol. 1, No. 3, March 1961, pp. 97-104.

5. "A Non-Destructive Three-Dimensional Strain Analysis Method," with A. J. Durelli, Journal of Applied Mechanics, Vol. 28, Series E., No. 1, March 1961, pp. 83-86.

6. "Stress Distribution Around a Circular Hole in a Semi-Infinite Plate Under Impact at Different Points on the Edge," with A. J. Durelli, Developments in Mechanics, Vol. 1, Plenum Press, New York, 1961, pp. 268-285.

7. "Shrinkage Stresses Around Rigid Inclusions," with A. J. Durelli, Experimental Mechanics, Vol 2, No. 8, August 1962, pp. 240-244.

8. "A Short Bibliography of Recent British Work in Photoelasticity," with J. W. Dally and W. F. Riley, Proceedings of the International Symposium on Photoelasticity, Pergamon Press, New York, 1963.

9. "The Influence of Stress Gradient Upon Fracture of Brittle Materials," with N. A. Weil, ASME Paper No. 63-WA-228, November 1963.

10. "Analysis of the Fracture Probabilities in Nonuniformly Stressed Brittle Materials," with N. A. Weil, Journal of the American Ceramic Society, Vol. 47, No. 6, June 1964, pp. 268-274.

11. "Stress Distribution on the Boundary of a Circular Hole in a Large Plate Due to an Air Stock Wave Traveling Along an Edge of the Plate," with W. F. Riley, Journal of Applied Mechanics, Vol. 31, Series E, No. 3, September 1964, pp. 402-408.

12. "Quasi-Static Properties of a Photoviscoelastic Material," Experimental Mechanics, Vol. 5, No. 3, March 1965, pp. 83-89. 
13. "Experimental Methods for Dynamic Stress Analysis in Viscoelastic Materials," Journal of Applied Mechanics, Vol. 32, Series 3, No. 3, Sept. 1965, pp. 598-606.

14. "Dynamic Properties of a Photoviscoelastic Material," Proceedings of the Second International Congress on Experimental Mechanics, September 28-October 1, 1965, Washington, DC; also, Experimental Mechanics, Vol. 6, No. 5, May 1966, pp. 225-234.

15. "Stresses Around a Circular Hole in a Viscoelastic Plate Subjected to Point Impact on One Edge," Developments in Mechanics, ed. by T. C. Huang and M. W. Johnson, Jr., Vol. 3, Part I, John Wiley and Sons, New York, 1966, pp. 491-547.

16. "Mechanical and Optical Characterization of Plasticized Polyvinyl Chloride," Transactions of the Society of Rheology, Vol. 10, Part 1, 1966, pp. 25-49.

17. "Viscoelastic Wave Interaction with Cylindrical Cavity," Journal of the Engineering Mechanics Division, ASCE, Vol. 92, No. EM6, Proceedings Paper 4999, December 1966, pp. 25-42.

18. "Ultrahigh-Speed Framing Photography Employing a Multiple-Pulsed Ruby Laser and a 'Smear Type' Camera: Application to Dynamic Photoelasticity," with R. E. Rowlands and C. E. Taylor, in High-Speed Photography, ed. by N.R. Nilsson and L. Hogberg, John Wiley and Sons, New York, 1968, pp. 275-280.

19. "Three-Dimensional Photoelastic Analysis of a Fiber-Reinforced Composite Model," with R. H. Marloff, Experimental Mechanics, Vol. 9, No. 4, April 1969, pp. 156-162.

20. "A Multiple-Pulse Ruby Laser System for Dynamic Photomechanics. Applications to Transmitted and Scattered-Light Photoelasticity," with R. E. Rowlands and C. E. Taylor, Experimental Mechanics, Vol. 9, No. 9, September 1969, pp. 385-393.

21. "Photoelastic Studies of Wave Propagation in Layered Media," Proceedings of Instrumentation for Nuclear Weapons Effects Simulation Symposium, Air Force Special Weapons Center, Kirtland Air Force Base, NM, AFSWC-TR-5, Vol. IV, March 1970, pp. 277-309.

22. "Photoelastic Study of Crack Propagation in Composite Models," Journal of Composite Materials, Vol. 4, April 1970, pp. 178-190.

23. "Photoelastic Analysis of Stresses Around Oblique Holes," Experimental Mechanics, Vol. 10, No. 11, November 1970, pp. 467-473.

24. "Determination of Strain Concentration in Composites by Moiré Techniques," with R. E. Rowlands, Journal of Composite Materials, Vol. 5, April 1971, pp. 250-254.

25. "Moiré Analysis of the Interlaminar Shear Edge Effect in Laminated Composites," with R. B. Pipes, Journal of Composite Materials, Vol. 5, April 1971, pp. 255-259.

26. "Wave Propagation in Layered Model Due to Point Source Loading in LowImpedance Medium," with R. L. Marino, Experimental Mechanics, Vol. 11, No. 5, May 1971, pp. 210-216. 
27. "Wave Propagation in Layered Model Due to Point Source Loading in HighImpedance Medium," with R. L. Marino, Geophysics, Vol. 36, No. 3, June 1971, pp. 517-532.

28. "Study of Lined and Unlined Cavities in Biaxially Loaded Rocks," with R. E. Rowlands, Dynamic Rock Properties, ed. by G. B. Clark, American Institute of Mining, Metallurgical and Petroleum Engineers, New York, 1971, pp. 877-902.

29. "Deformation and Fracture Around Lined and Unlined Cylindrical Cavities in Rock," Experimental Mechanics, Vol. 11, No. 10, October 1971, pp. 473-480.

30. "Three-Dimensional Photoelastic Analysis of Hypoid Gears," Journal of Engineering for Industry, Trans. of ASME, Vol. 93, Series B, No. 4, November 1971, pp. 1275-1279.

31. "Study of Lined and Unlined Cavities in Uniaxially Loaded Rock," with R. E. Rowlands, Proceedings of the Second Annual Meeting of the Nuclear Survivability Working Group, San Bernardino, CA, 1971.

32. "Application of Holography to Heterogeneous Anisotropic Composite Plates," with R. E. Rowlands, Experimental Mechanics, Vol. 12, No. 2, February 1972, pp. 7582.

33. "The Embedded Strain Gage Technique for Testing Boron/Epoxy Composites," with J. L. Mullineaux, F. J. Ahimaz and T. Liber, Composite Materials: Testing and Design, ASTM STP 497, American Society for Testing and Materials, 1972, pp. 257-272.

34. "Experimental Stress Analysis of Composite Materials," with R. E. Rowlands, ASME Paper No. 72-DE-6, May 1972.

35. "Stress Concentration and Strength Reduction in Composite Plates with Cutouts," with R. E. Rowlands and J. B. Whiteside, Proceedings of Conference on Fibrous Composites in Flight Vehicle Design, AFFDL-TR-72-130, September 1972.

36. "Stress and Failure Analysis of Glass/Epoxy Composite Plate with Circular Hole," with R. E. Rowlands and J. B. Whiteside, Experimental Mechanics, Vol. 13, No. 1, January 1973, pp. 31-37.

37. "Higher-Order Numerical Differentiation of Experimental Information," with R. E. Rowlands, T. Liber and P. G. Rose, Experimental Mechanics, Vol. 13, No. 3, March 1973, pp. 105-112.

38. "Deformation and Failure of Boron/Epoxy Plates with Circular Hole," with R. E. Rowlands and J. B. Whiteside, Analysis of the Test Methods for High Modulus Fibers and Composites, ASTM STP 521, American Society for Testing and Materials, 1973, pp. 143-164.

39. "Mechanical Behavior of a Graphite/Epoxy Laminate Containing a Hole," with R. E. Rowlands and J. B. Whiteside, Proceedings of the Sixth St. Louis Symposium on Composite Materials, 1973. 
40. "Strain Analysis of Composites by Moiré Methods," with R. E. Rowlands and D. Post, Experimental Mechanics, Vol. 13, No. 6, June 1973, pp. 246-252.

41. "Stress Analysis of Anisotropic Laminated Plates" with R. E. Rowlands, T. Liber and P. G. Rose, Proceedings of Thirteenth International Congress of Theoretical and Applied Mechanics, Moscow, USSR, August 1972; also, AIAA Journal, Vol. 12, July 1974, pp. 903-908.

42. "Effects of Material and Stacking Sequence on Behavior of Composite Plates with Holes," with R. E. Rowlands and J. B. Whiteside, Proceedings of Third International Congress on Experimental Mechanics, 1974; also Experimental Mechanics, Vol. 14, No. 1, January 1974, pp. 1-9.

43. "Geometric and Loading Effects on Strength of Composite Plates with Cutouts," with R. E. Rowlands and J. B. Whiteside, Composite Materials: Testing and Design (Third Conference), ASTM STP 546, American Society for Testing and Materials, 1974, pp. 361-375.

44. "Photoelastic Study of Water Jet Impact," with R. E. Rowlands and T. J. Labus, Proceedings of Second International Symposium on Jet Cutting Technology, Paper A1, April 2-4, 1974, Cambridge, England.

45. "Wave Motion in Anisotropic Media by Dynamic Photomechnics," with R. E. Rowlands and R. Prabhakaran, Experimental Mechanics, Vol. 14, No. 11, November 1974, pp. 433-439.

46. "Optical Methods for Testing Composite Materials," Proceedings, 39th Meeting of the Structures and Materials Panel on "Failure Modes of Composite Materials with Organic Matrices and Their Consequences on Design," AGARD-NATO, Munich, West Germany, October 6-12, 1974; AGARD-CP-163, 1975.

47. "The Effects of Thermal Cycling on Advanced Composite Angle-Ply Laminates," with T. Liber and C. C. Chamis, Proceedings of 30th SPI Reinforced Plastics/Composites Institute, Section 18-B, Washington, DC, February 4-7, 1975.

48. "Speckle-Shearing Interferometric Technique: A Full-Field Strain Gage," with Y. Y. Hung and R. E. Rowlands, Applied Optics, Vol. 14, March 1975, pp. 618-622.

49. "Measurement of Residual Strains in Boron/Epoxy and Glass/Epoxy Laminates," with T. Liber and C. C. Chamis, Composite Reliability, ASTM STP 580, American Society for Testing and Materials, 1975, pp. 340-351.

50. "Residual Stresses in Angle-Ply Polymer Matrix Composites," Proceedings of Workshop in Nondestructive Evaluation of Residual Stresses, San Antonio, TX, August 13, 14, 1975, NTIAC-76-2, pp. 111-124.

51. "Experimental Studies of Water Jet Impact," Workshop on Application of High Pressure Water Jet Cutting Technology, University of Missouri at Rolla, Rolla, MO, November 10-11, 1975.

52. "On Wave and Fracture Propagation in Rock Media," with R. E. Rowlands, Experimental Mechanics, Vol. 15, No. 12, December 1975, pp. 449-457. 
53. "Effects of Tensile Load Cycling on Advanced Composite Angle-Ply Laminates," with T. Liber, Proceedings of 31st SPI Reinforced Plastics/Composites Institute, Section 21-E, Washington, DC, February 3-6, 1976.

54. "Experimental Studies of Water Jet Impact on Rock and Rock-Like Materials," Proceedings of Third International Symposium on Jet Cutting Technology, Paper B3, Chicago, IL May 11-13, 1976.

55. "Measurement of Lamination Residual Strains in Graphite Fiber Laminates," with T. Liber, Proceedings of Second International Conference on Mechanical Behavior of Materials, ICM-II, Boston, MA, August 16-20, 1976.

56. "Relaxation of Residual Stresses in Angle-Ply Composite Laminates," with T. Liber, Proceedings of Army Symposium on Solid Mechanics, 1976; Composite Materials; The Influence of Mechanics of Failure on Design, South Yarmouth, MA, September 14-16, 1976.

57. "Effect of Laminate Construction on Residual Stresses in Composites," with T. Liber, Experimental Mechanics, Vol. 17, No. 1, January 1977, pp. 21-25.

58. "Lamination Residual Strains and Stresses in Hybrid Laminates," with T. Liber, Composite Materials: Testing and Design (Fourth Conference), ASTM STP 617, American Society for Testing and Materials, 1977, pp. 331-343.

59. "Failure Mechanisms in Fiber Reinforced Composites," Proceedings of ARPA/AFML Review of Progress in Quantitative NDE, Cornell University, Ithaca, NY, June 14-17, 1977, AFML-TR-78-55.

60. "Effects of Mechanical and Thermal Cycling on Composite and Hybrid Laminates with Residual Stresses," Proceedings of 14th Annual Meeting of Society of Engineering Science, Lehigh University, Bethlehem, PA, November 14-16, 1977, pp. 237-246.

61. "Static Behavior and the Effects of Thermal Cycling in Hybrid Laminates," with T. Liber, and C. C. Chamis, Proceedings of 32nd SPI Reinforced Plastics/Composites Institute, Section 15-D, Washington, DC, February 8-11, 1977; also Polymer Engineering and Science, Vol. 18, No. 2, February 1978, pp. 157-166.

62. "Thermal Deformations and Residual Stresses in Fiber Composites," Proceedings of 1977 International Symposium on Thermal Expansion of Solids, Hecla Island, Manitoba, Canada, August 29-31, 1977; Thermal Expansion 6, ed. by Ian D. Peggs, Plenum Publishing Corp., New York, 1978, pp. 203-221.

63. "Full-Field Optical Strain Measurement Having Postrecording Sensitivity and Direction Selectivity," with Y. Y. Hung and R. E. Rowlands, Experimental Mechanics, Vol. 18, No. 2, February 1978, pp. 56-60.

64. "Edgeless Composite Laminate Specimen for Static and Fatigue Testing," with T. Liber, Proceedings of 33rd SPI Reinforced Plastics/Composites Institute, Section 12-B, Washington, DC, February 1978. 
65. "Testing of Fiber Composites at High Strain Rates," with T. Liber, Proceedings of Second International Conference on Composite Materials, ICCM/2, Toronto, Canada, April 16-20, 1978, pp. 1003-1018.

66. "Behavior of Uniaxially Loaded Graphite/Epoxy Plates with Holes," Proceedings of Second International Conference on Composite Materials, ICCM/2, Toronto, Canada, April 16-20, 1978, pp. 1019-1034.

67. "Strain and Failure Analysis in Graphite/Epoxy Plates with Cracks," Experimental Mechanics, Vol. 18, No. 7, July 1978, pp. 246-252.

68. "Deformation and Failure of Composite Laminates with Cracks in Biaxial Stress Fields,"Proceedings of Sixth International Conference on Experimental Stress Analysis, VDI-Berichte Nr. 313, Munich, West Germany, September 18 - 22, 1978, pp. 705-710.

69. "Nondestructive Evaluation of Composite Materials," with T. Liber, Proceedings of Fourth International Conference on Automated Inspection and Product Control, Chicago, IL, November 7-9, 1978, pp. 263-292.

70. "Ultrasonic Techniques for Inspecting Flat and Cylindrical Composite Specimens," with T. Liber and S.W. Schramm, Nondestructive Evaluation and Flaw Criticality for Composite Materials, ASTM STP 696, American Society for Testing and Materials, 1979, pp. 5-25.

71. "Wave Propagation in Transversely Impacted Composite Laminates," with T. Liber, and R. LaBedz, Experimental Mechanics, Vol. 19, No. 1, January 1979, pp. 9-16.

72. "Effects of Material, Geometric and Loading Parameters on Behavior of Composites," Proceedings of 34th SPI Reinforced Plastics/Composites Institute, Section 20-B, New Orleans, LA, January 19-February 2, 1979.

73. "Fabrication and Testing of Composite Ring Specimens," with T. Liber, R. LaBedz and T. Niiro, Proceedings of 34th SPI Reinforced Plastics/Composites Institute, Section 22-B, New Orleans, LA, January 29-February 2, 1979.

74. "Nondestructive Evaluation Techniques for Composite Materials," with T. Liber, Proceedings of 12th Symposium on Nondestructive Evaluation, San Antonio, TX, April 24-26, 1979.

75. "Nondestructive Monitoring of Flaw Growth in Graphite/Epoxy Laminates Under Spectrum Fatigue Loading," with S. W. Schramm and T. Liber, Proceedings of ARPA/AF Review of Progress in Quantitative NDE, La Jolla, CA, July 8-13, 1979; AFWAL-TR-80-4078.

76. "Load Introduction with Tubular Composite Structural Members," with R. Vanderby, G.M. Koller and T. Liber, Proceedings of Third International Conference on Vehicle Structural Mechanics, Troy, MI, October 10-12, 1979. 
77. "Load Introduction Problems with Tubular Composite Structural Members," with R. Vanderby, G.M. Koller and T. Liber, Proceedings of First International Automotive Fuel Economy Research Conference, Department of Transportation, National Highway Traffic Safety Administration, Washington, DC, October 31November 2, 1979.

78. "Ultrasonic Monitoring of Flaw Growth in Graphite/Epoxy Laminates Under Fatigue Loading," with S. W. Schramm and T. Liber, Proceedings of Conference on Advanced Composites-Special Topics, El Segundo, CA, December 4-6, 1979.

79. Behavior of Graphite/Epoxy Plates with Holes Under Biaxial Loading," Experimental Mechanics, Vol. 20, No. 1, January 1980, pp. 1-8.

80. "Nondestructive Characterization of Flaw Growth in Graphite/Epoxy Composites," with S. W. Schramm and W. G. Hamilton, Proceedings of 35th Annual Conference of SPI Reinforced Plastics/Composites Institute, Section 12-E, New Orleans, LA, Feb. 4-8, 1980.

81. "Holographically Determined Isopachics and Isochromatics in the Neighborhood of a Crack in a Glass-Composite," with R. E. Rowlands, T. D. Dudderar and R. Prabhakaran, Experimental Mechanics, Vol. 20, No. 2, February 1980, pp. 53-56.

82. "Thermal Deformations and Stresses in Composite Materials," Thermal Stresses in Severe Environments, ed. by D.P.H. Hasselman and R. A. Heller, Plenum Press, New York, 1980, pp. 607-628.

83. "Nondestructive Evaluation of Graphite/Epoxy Composite Damage," with S. W. Schramm and W. G. Hamilton, Proceedings of DARPA/AFML Review of Progress in Quantitative NDE, La Jolla, CA, July 1980.

84. "Analysis of Tubular Specimen for Biaxial Testing of Composite Laminates," with T. Liber, R. Vanderby and G. M. Koller, Advances in Composite Materials, Vol. 1, ed. by A. R. Bunsell, C. Bathias, A. Martrenchar, D. Menkes, G. Verchery, ICCM 3, Third International Conference on Composite Materials, Paris, France; Pergamon Press, New York, 1980, pp. 840-855.

85. "Evaluation of Sensitivity of Ultrasonic Detection of Delamination in Graphite/Epoxy Laminates," with S. W. Schramm and W. G. Hamilton, Mechanics of Nondestructive Testing, ed. by W. W. Stinchcomb, Pergamon Press, New York, 1980, pp. 309-324.

86. "New Method for Testing Composites at Very High Strain Rates," with R. LaBedz and T. Liber, Experimental Mechanics, Vol. 21, No. 2, February 1981, pp. 71-77.

87. "Biaxial Testing of Graphite/Epoxy Laminates with Cracks," Test Methods and Design Allowables for Fibrous Composites, ASTM STP 734, American Society for Testing and Materials, 1981, pp. 109-128. 
88. "Evaluation of Sensitivity of Ultrasonic Detection of Disbonds in Graphite/Epoxy to Metal Joints," with S. W. Schramm and W. G. Hamilton, $36^{\text {th }}$ SPI Annual Technical Conference, Reinforced Plastics/Composites Institute, the Society of Plastics Industry, Section 23-D, February 1981.

89. "Fatigue Monitoring in Composites by Ultrasonic Mapping," with S. W. Schramm and T. Liber, Materials Evaluation, Vol. 39, No. 9, August 1981, pp. 834-839.

90. "Evaluation of Sensitivity of Ultrasonic Detection of Disbonds in Graphite/Epoxy to Metal Joints," with S. W. Schramm and W. G. Hamilton, Polymer-Plastics Technology and Engineering, Vol. 18, No. 1, 1982, pp. 65-80.

91. "Biaxial Testing of $\left[0_{2} / \pm 45\right]_{s}$ Graphite/Epoxy Plates with Holes," Experimental Mechanics, Vol. 22, May 1982, pp. 188-195.

92. "Strain Rate Characterization of Unidirectional Graphite/Epoxy Composite," with W. G. Hamilton and R. H. LaBedz, Composite Materials: Testing and Design (Sixth Conference), ASTM STP 787, ed. by I. M. Daniel, American Society for Testing and Materials, 1982, pp. 393-413.

93. "Nondestructive Evaluation of Metal Matrix Composites," with S. W. Schramm, Proceedings of AF/DARPA Review of Progress in Quantitative NDE, University of California, San Diego, CA, August 1982.

94. "Failure Mechanisms and Fracture of Composite Laminates with Stress Concentrations," keynote address, Proceedings of the Seventh International Conference on Experimental Stress Analysis, Haifa, Israel, August 1982, pp. 1-20.

95. "Method for Compression Testing of Composite Materials at High Strain Rates," with R. H. LaBedz, Compression Testing of Homogeneous Materials and Composites, ASTM STP 808, R. Chait and R. Papirno, eds., American Society for Testing and Materials, 1983, pp. 121-139.

96. "Experimental Mechanics of Composite Materials," in Mechanics of Composite Materials, Recent Advances, Z. Hashin and C. T. Herakovich, eds., Pergamon Press, New York, 1983, pp. 473-496.

97. "Experimental Methods in Applied Mechanics," Journal of Applied Mechanics, (50th Anniversary Issue), Vol. 50, Dec. 1983, pp. 963-976.

98. "Development and Characterization of Orthotropic Birefringent Materials," with G. M. Koller and T. Niiro, Experimental Mechanics, Vol. 24, No. 2, June 1984, pp. 135-143.

99. "Damage Accumulation and Residual Strength Degradation in Graphite/Epoxy Laminates," with A. Charewicz, Proceedings of the Technical Co-operation Workshop on "Failure Modes and NDE of Composites," Plymouth, England, July 1984. 
100. "Determination of Fracture Toughness by Means of Photoelastic Coating," with H. C. Soo, Proceedings of Fifth International Congress on Experimental Mechanics, Montreal, Canada, June 1984, pp. 520-525; also Experimental Mechanics, Vol. 27, No. 1, March 1987, pp. 10-13.

101."Mixed Mode Failure of Composite Laminates with Cracks," Proceedings of Fifth International Congress on Experimental Mechanics, Montreal, Canada, June 1984, pp. 320-327; also Experimental Mechanics, Vol. 25, No. 4, December 1985, pp. 413-420.

102."Effects of Strain Rate on Delamination Fracture Toughness of Graphite/Epoxy," with A. A. Aliyu, Delamination and Debonding of Materials, ASTM STP 876, W.S. Johnson, ed., American Society for Testing and Materials, 1985, pp. 336-348.

103."Deformation and Failure of Transversely Loaded Composite Plates," with S-C. Wooh, Proceedings of 1985 Spring Conference of the SEM, Las Vegas, NV, June 1985, pp.369-377.

104."Embedded Gages for Study of Transient Deformation and Dynamic Fracture in Composites," with S.-C. Wooh, Proceedings of Fall Meeting of SEM, Grenelefe, FL, November 17-20, 1985, pp. 62-68.

105."Deformation and Damage of Composite Plates Under Impact Loading," with S.-C. Wooh, Proceedings of International Conference on Composite Materials and Structures, (Beijing, China, June 1986) ed. by T. T. Loo and C. T. Sun, Technomic Publishing Co., Lancaster, PA, 1986, pp. 630-637.

106."Detection and Characterization of Damage in Thick Composites," with J. D. Achenbach, G. Kechter and S.-C. Wooh, Proceedings of Nondestructive Testing and Evaluation of Advanced Materials and Composites Conference, Colorado Springs, CO, 1986, pp. 121-133.

107."Fatigue Damage Mechanisms and Residual Properties of Graphite/Epoxy Laminates," with A. Charewicz, Mechanics of Damage and Fatigue, IUTAM Symposium on Mechanics of Damage and Fatigue, Haifa and Tel Aviv, Israel, 1985; also Engineering Fracture Mechanics, Vol. 25, No. 5/6, 1986, pp. 793-808.

108."Damage Mechanisms and Accumulation in Graphite/Epoxy Laminates," with A. Charewicz, Composite Materials: Fatigue and Fracture, ASTM STP 907, H. T. Hahn, ed., American Society for Testing and Materials, 1986, pp. 274-297.

109."Residual Stresses and Warpage in Circuit Board Composite Laminates," with I. G. Zewi and J. T. Gotro, Proceedings of Fall Meeting of SEM, Grenelefe, FL, November 17-20, 1985, pp. 19-26; also Experimental Mechanics, Vol. 27, No. 1, March 1987, pp. 44-50.

110. "Rate Effects on Delamination Fracture Toughness of a Toughened Graphite/Epoxy Composite," with I. Shareef and A. A. Aliyu, Toughened Composites, ASTM STP 937, N. J. Johnston, ed., American Society for Testing and Materials, Philadelphia, 1987, pp. 260-274. 
111."Nondestructive Characterization of Impact Damage in Graphite/Epoxy Laminates," with S.-C. Wooh, Solid Mechanics Research for Quantitative NonDestructive Evaluation, ed. by J. D. Achenbach and Y. Rajapakse, Martinus Nijhoff, Boston, 1987, pp. 203-215.

112."SEM Fractography of Pure and Mixed-Mode Interlaminar Fractures in Graphite/Epoxy Composites," with L. Arcan and M. Arcan, Fractography of Modern Engineering Materials, ASTM STP 948, J. Masters and J. Au, eds., American Society for Testing and Materials, Philadelphia, 1987, pp. 41-67.

113."Defect and Damage Characterization in Composite Materials," with S.-C. Wooh and J.- W. Lee, Review of Progress in QNDE, Vol. 6B, ed. by D. O. Thompson and D.E. Chimenti, Plenum Press, New York, 1987, pp. 1195-1202.

114."The Influence of Lamination Parameters on Warpage of Woven-Glass/Epoxy Laminates," with D. Karalekas and J.T. Gotro, ANTEC 87, Proceedings of 45th Annual Technical Conference, the Society of Plastics Engineers, Los Angeles, CA, May 1987, pp. 339-342.

115."Damage Mechanisms and Stiffness Degradation in Graphite/Epoxy Composites," with G. Yaniv and J.W. Lee, ICCM and ECCM (Sixth International Conference on Composite Materials and Second European Conference on Composite Materials), ed. by F. L. Matthews, N.C.R. Buskell, J. M. Hodgkinson and J. Morton, Elsevier Applied Science, London, 1987, Vol. 4, pp. 4.129-4.138.

116. "Rate Effects on Delamination Fracture Toughness of Graphite/Epoxy Composites," with G. Yaniv and J. W. Auser, Composite Structures - 4, (Proceedings of Fourth International Conference on Composite Structures), Paisley, Scotland, 1987, Elsevier Applied Science, London \& New York, pp. 2.258-2.272.

117."Method for Hygrothermal Characterization of Graphite/Epoxy Composite," with G. Yaniv and G. Peimanidis, Journal of Composites Technology and Research, Vol. 9, No. 1, Spring 1987, pp. 21-25.

118. "Height-Tapered Double Cantilever Beam Specimen for Study of Rate Effects on Fracture Toughness of Composites," with G. Yaniv, Composite Materials: Testing and Design, ASTM STP 972, J. D. Whitcomb, ed., American Society for Testing and Materials, 1988, pp. 241-258.

119."Acoustographic Nondestructive Evaluation of Composite Materials," with S.C. Wooh, J. S. Sandhu, and W. Hamidzada, Review of Progress in QNDE, ed. by D. O. Thompson and D. E. Chimenti, Plenum Publishing Corp., New York, 1988, Vol. 7A, pp. 325-332.

120."Hygrothermal and Strain Rate Effects on Properties of Graphite/Epoxy Composites," with G. Yaniv and G. Peimanidis, Journal of Engineering Materials and Technology, Vol. 110, April 1988, pp. 169-173. 
121."Damage Development and Property Degradation of Composite Materials," with J. W. Lee and G. Yaniv, Mechanics of Composite Materials, ed. by G. J. Dvorak and N. Laws, ASME AMD-Vol. 92, 1988, pp. 149-160.

122."Enhancement Techniques for Ultrasonic Imaging of Damage in Composite Materials," with S.-C. Wooh, Proc. of Symposium on New Directions in Nondestructive Evaluation of Advanced Materials, ed. by J. L. Rose and A. A. Tseng, ASME Winter Annual Meeting, Chicago, IL, Nov. 27-Dec. 2, 1988, pp. 5362.

123."Environmental Effects on High Strain Rate Properties of Graphite/Epoxy Composites," with G. Yaniv and G. Peimanidis, Test Methods and Design Allowables for Fiber Composites, ASTM STP 1003, C. C. Chamis, ed., American Society for Testing and Materials, 1989, pp. 16-30.

124."Method for Monitoring In-Plane Shear Modulus in Fatigue Testing of Composites," with G. Yaniv and J.-W. Lee, Test Methods and Design Allowables for Fiber Composites, ASTM STP 1003, C. C. Chamis, ed., American Society for Testing and Materials, 1989, pp. 276-284.

125."Fatigue Life Prediction of Crossply Composite Laminates," with G. Yaniv and J.W. Lee, Composite Materials: Fatigue and Fracture, ASTM STP 1012, P.A. Lagace, Ed., American Society for Testing and Materials, 1989, pp. 19-28.

126."Ultrasonic Techniques for Characterization of Manufacturing Defects in Thick Composites," with S.-C. Wooh, Review of Progress in Quantitative NDE, ed. by D. O. Thompson and D.E. Chimenti, Plenum Publishing Corp., New York, 1989, Vol. 8B, pp. 1605-1612.

127."Determination of Chemical Cure Shrinkage in Woven-Glass/Epoxy Laminates," with T. M. Wang, D. Karalekas and J. T. Gotro, Proc. of ANTEC 1989 Conf., Soc. of Plastics Engineers, New York, NY, May 1989, Technical Papers Volume XXXV, pp. 632-634.

128."Damage Development in Composite Laminates under Monotonic Loading," with J.W. Lee, Proc. of ANTEC 89 Conf., Society of Plastics Engineers, New York, NY, May 1989, Technical Papers Volume XXXV, pp. 1577-1580.

129."Failure Mechanisms in Ceramic Matrix Composites," with G. Anastassopoulos and J.-W. Lee, Proc. of 1989 SEM Spring Conf. on Exper. Mechanics, Cambridge, MA, May 29-June 1, 1989, pp. 832-838.

130. "Experimental Micromechanics of Brittle-Matrix Composites," with G. Anastassopoulos and J.-W. Lee, ASME AMD-Vol. 102, ed. by W. N. Sharpe, Jr., 1989, pp. 133-146.

131."Mechanical Testing: New Challenges," Advanced Materials and Processes, Vol. 136, No. 5, Nov. 1989, pp. 42-43. 
132."Damage Development and Shear Modulus Degradation in Graphite/Epoxy Laminates," with G. Yaniv and J.W. Lee, Composite Materials: Testing and Design, (Ninth Vol.), ASTM STP 1059, S. P. Garbo, ed., Amer. Soc. for Testing and Materials, Philadelphia, 1990, pp. 404-416.

133."Thermomechanical Behavior of Multilayer Structures in Microelectronics," with T.-M. Wang and J. T. Gotro, J. of Electronic Packaging, Trans. ASME, Vol. 112, March 1990, pp. 11-15.

134."Enhancement Techniques for Ultrasonic Nondestructive Evaluation of Composite Materials" with S.-C. Wooh, ASME J. of Eng. Materials and Technology, Trans. ASME, Vol. 112, Apr. 1990, pp. 175-182.

135."Ultrasonic Characterization of Defects and Damage in Thick Composites," with S.-C. Wooh, Review of Progress in Quantitative Nondestructive Evaluation, Vol. 9, ed. by D. O. Thompson and D. E. Chimenti, Plenum Press, New York, 1990, pp. 1489-1496.

136. "Three-Dimensional Imaging of Impact Damage in Composite Laminates," with S.-C. Wooh, Review of Progress in Quantitative Nondestructive Evaluation, Vol. 9, ed. by D. O. Thompson and D. E. Chimenti, Plenum Press, New York, 1990, pp. 1513-1520.

137."Torsional Response of Rectangular Composite Laminates," with C.-L. Tsai and G. Yaniv, J. Applied Mechanics, Vol. 57, June 1990, pp. 383-387.

138. "Nondestructive Evaluation of Damage Development in Composite Materials," with S.-C. Wooh and J.-W. Lee, Elastic Waves and Ultrasonic Nondestructive Evaluation, Proc. IUTAM Symposium, Boulder, CO, ed. by S. K. Datta, J. D. Achenbach and Y.D.S. Rajapakse, North Holland Publ. Co., New York, 1990, pp. 183-189.

139."Progressive Transverse Cracking of Crossply Composite Laminates," with J.-W. Lee, J. of Comp. Materials, Vol. 24, No. 11, November 1990, pp. 1225-1243.

140."Damage Development in Composite Laminates under Monotonic Loading," with J.-W. Lee, J. of Comp. Technology and Research, Vol. 12, No. 2, Summer 1990, pp. 98-102.

141."Determination of Chemical Cure Shrinkage in Composite Laminates," with T.-M. Wang, D. Karalekas and J. T. Gotro, J. of Comp. Technology and Research, Vol. 12, No. 3, Fall 1990, pp. 172-176.

142."Determination of In-Plane and Out-of-Plane Shear Moduli of Composite Materials," with C.-L. Tsai, Experimental Mechanics, Vol. 30, No. 3, Sept. 1990, pp. 295-299.

143."Ultrasonic Methods for Mechanical Characterization of Fiber-Reinforced Composite Materials," with S.-C. Wooh, 5th U.S.-Japan Conference on Composite Materials, June 1990. 
144."Deformation and Damage of Composite Laminates under Impact Loading," with S.-C. Wooh, Impact and Elastodynamics of Composites, AMD-Vol. 116, ed. by A. K. Mal and Y.D.S. Rajapakse, ASME, New York, 1990, pp. 11-26.

145."Progressive Matrix Cracking of Crossply Composite Laminates under Biaxial Loading," with C.-L. Tsai and J.-W. Lee, Microcracking Induced Damage in Composites, AMD-Vol. 111, MD-Vol. 22, ed. by G. J. Dvorak and D. C. Lagoudas, ASME, New York, 1990, pp. 9-18.

146."Investigation of Interphase Stiffness in a Ceramic Matrix Composite," with G. Anastassopoulos, Advanced Composites in Emerging Technologies, ed. by S. A. Paipetis and T. P. Philippidis, Amatec Publ., Patras, Greece, 1991, pp. 448-459.

147."Micromechanical Model for Thermomechanical Behavior of a Silicon Carbide/Aluminum Composite," with E. E. Gdoutos and D. Karalekas, Advanced Composites in Emerging Technologies, ed. by S. A. Paipetis and T. P. Philippidis, Amatec Publ., Patras, Greece, 1991, pp. 216-232.

148."Thermal Stress Analysis of Silicon Carbide/Aluminum Composite," with E. E. Gdoutos and D. Karalekas, Experimental Mechanics, Vol 31, No. 3, Sept. 1991, pp. 202-208.

149. "Nondestructive Determination of Elastic Constants of Composite Materials," with S.-C. Wooh, Review of Progress in QNDE, Vol. 10B, ed. by D. O. Thompson and D. E. Chimenti, Plenum Press, New York, 1991, pp. 1445-1452.

150."Characterization of Porosity in Thick Graphite/Epoxy Composites," with S.-C. Wooh, and I. Komsky, Review of Progress in QNDE, Vol. 10B, ed. by D. O. Thompson and D. E. Chimenti, Plenum Press, New York, 1991, pp. 1607-1614.

151."Micromechanical Analysis of Filamentary Metal Matrix Composites under Longitudinal Loading," with E. E. Gdoutos and D. Karalekas, Journal of Composites Technology and Research, Vol. 13, No. 3, Fall 1991, pp. 168-174.

152."Micromechanical Analysis of Nonlinear Thermal Deformation of Filamentary Metal Matrix Composites," with D. Karalekas and E. E. Gdoutos, Computational Mechanics, Vol 9, 1991, No. 1, pp. 17-26.

153."The Behavior of Cracked Cross-Ply Composite Laminates Under Simple Shear Loading," with C.-L. Tsai, Composites Engineering, Vol. 1, No. 1, 1991, pp. 3-11.

154."Analytical/Experimental Study of Cracking in Composite Laminates under Biaxial Loading," with C.-L. Tsai, Composites Engineering, Vol. 1, No. 6, 1991, pp. 355362.

155."New Test Method and Monitoring Technique to Evaluate Mode III and Mixed Mode Fracture Toughness in Composite Laminates," with G. Yaniv, Composites: Design, Manufacture and Application, ICCM/VIII, Section 30-39, ed. by S.-W. Tsai and G. Springer, SAMPE, Covina, CA, 1991, Section 36A. 
156. "Analytical/Experimental Study of Cracking in Composite Laminates under Biaxial Loading," with C. L. Tsai Composites: Design, Manufacture and Application, ICCM/VIII, Section 30-39, ed. by S.-W. Tsai and G. Springer, SAMPE, Covina, CA, 1991, Section 37C.

157."Mechanical Characterization of a Unidirectional Composite by Ultrasonic Methods," with S.-C. Wooh, Journal of the Acoustical Society of America, Vol. 90, No. 6, 1991, pp. 3248-3253.

158."Studies of the Warpage of Woven-Glass/Epoxy Laminates," with D. Karalekas and J. T. Gotro, Phase Interaction in Composite Materials, ed. by S. A. Paipetis and G. C. Papanicolaou, Omega Scientific, Oxon, England, 1992, pp. 574-584.

159."Equivalence of Environmental and Strain Rate Parameters in Characterization of Graphite/Epoxy Composite," with G. Peimanidis and G. Yaniv, Phase Interaction in Composite Materials, ed. by S. A. Paipetis and G. C. Papanicolaou, Omega Scientific, Oxon, England, 1992, pp. 585-592.

160."Deformation and Failure of Longitudinally Loaded Brittle-Matrix Composites," with J.-W. Lee, ASTM STP, Composite Materials: Testing and Design, (Tenth Volume), ASTM STP 1120, Glenn C. Grimes, ed., Amer. Society for Testing and Materials, Philadelphia, 1992, pp. 204-221.

161."Thermoviscoelastic Analysis of Residual Stresses and Warpage in Composite Laminates," with T. M. Wang and J. T. Gotro, Journal of Composite Materials, Vol. 26, No. 6, 1992, pp. 883-899.

162."Quantitative Porosity Characterization of Composite Materials by Means of Ultrasonic Attenuation Measurements," J. Nondestructive Evaluation, Vol. 11, No. 1, 1992, pp. 1-8.

163."The Behavior of Cracked Cross-Ply Composite Laminates under Shear Loading," with C.-L. Tsai, Int. J. Solids and Structures, Vol. 29, No.24, 1992, pp. 3251-3267.

164."Ultrasonic Determination of Layer Orientation in Multilayer Multidirectional Composite Laminates," with I. N. Komsky and Y.-C. Lee, Review of Progress in QNDE, Vol. 11, ed. by D. O. Thompson and D. E. Chimenti, Plenum Press, New York, 1992, pp. 1615-1622.

165."Real-Time Ultrasonic Investigation of Damage Development in Ceramic-Matrix Composite," with S.-C. Wooh, Review of Progress in QNDE, Vol. 11, ed. by D. O. Thompson and D. E. Chimenti, Plenum Press, New York, 1992, pp. 1523-1530.

166."Torsion and Combined Tension-Torsion Fatigue of $63 \mathrm{Sn} \sim 37 \mathrm{~Pb}$ Solder," with R. Cortez, M. E. Fine and D. A. Jeanotte, Proc. of ASM 4th International Electronic Materials and Processing Congress, Montreal, 1992. 
167."Failure Mechanisms and Interfacial Shear Strength in Brittle-Matrix Composites," with G. Anastassopoulos and J.-W. Lee, AD-Vol. 29/AMD-Vol. 146, Advances in Experimental Mechanics and Biomimetics, ed. by W. F. Jones and J. M. Whitney, ASME 1992, pp. 57-69.

168. "Real-Time Ultrasonic Investigation of Fiber-Matrix Debonding in Ceramic-Matrix Composite," with S. C. Wooh, Review of Progress in QNDE, Vol. 12, ed. by D. O. Thompson and D. E. Chimenti, Plenum Press, New York, 1993, pp. 1483-1490.

169."Integrated Ultrasonic Technique for Characterization of Composite Materials," with I. N. Komsky and J. D. Achenbach, Review of Progress in QNDE, Vol. 12, ed. by D. O. Thompson and D. E. Chimenti, Plenum Press, New York, 1993, pp. 1257-1264.

170. "Characterization of Porosity in Thick Composites Using Ultrasonic Wave Velocity Measurements," with I. N. Komsky and S. C. Wooh, Review of Progress in QNDE, Vol. 12, ed. by D. O. Thompson and D. E. Chimenti, Plenum Press, New York, 1993, pp. 1273-1280.

171. "The Behavior of Ceramic Matrix Fibre Composites under Longitudinal Loading," with J.-W. Lee and G. Anastassopoulos, Composites Science and Technology, Vol. 46, 1993, pp. 105-113.

172."The Behavior of Cracked Crossply Composite Laminates Under General In-Plane Loading," with C.-L. Tsai, Damage in Composite Materials, Studies in Applied Mechanics, Vol. 34, ed. by G. Z. Voyiadjis, Elsevier Science Publishers, 1993, pp. 51-66.

173."Measurement of Longitudinal Shear Modulus of Single Fibers by Means of a Torsional Pendulum," with C.-L. Tsai and J.-J. Luo, Advanced Materials: Performance Through Technology Insertion, Vol. 38, Book 2, V. Bailey, G. Janicki and T. Haulik, eds., 38th International SAMPE Symposium, Society for the Advancement of Materials and Process Engin., Covina, CA, 1993, pp. 1861-1868.

174."Processing and Compressive Behavior of Thick Composites," with H.-M. Hsiao, S.-C. Wooh and J. Vittoser in Mechanics of Thick Composites, ed. by Y.D.S. Rajapakse, AMD-Vol. 162, ASME, June 1993, pp. 107-126.

175."Fracture of Hybrid Composite Materials Under Dynamic Loading," Proceedings of ICCM-9 Conference, Madrid, Spain, July 12-16, 1993.

176."Analysis of Curing Warpage in Multidirectional Composite Laminates," with T.M. Wang, Proceedings of Pacific International Conference on Aerospace Science and Technology, Vol. II, Tainan, Taiwan, December 1993, pp. 945-951.

177."Method for Thermomechanical Characterization of Single Fibers," with C.-L. Tsai, Composites Science and Technology, Vol. 50, 1994, pp. 7-12.

178."Real-Time Ultrasonic Monitoring of Fiber-Matrix Debonding in Ceramic Matrix Composite," with S.-C. Wooh, Mechanics of Materials, Vol. 17, 1994, pp. 379-388. 
179."Characterization of Fiber Waviness in Thick Composites Based on an Ultrasonic Ray Tracing Model," with S.-C. Wooh, Review of Progress in QNDE, ed. by D. O. Thompson and D. E. Chimenti, Plenum Press, New York, Vol. 13B, 1994, pp. 1291-1298.

180."Acoustic Emission Study of Failure Mechanisms in Ceramic Matrix Composite Under Longitudinal Tensile Loading," with J.-J. Luo and S.-C. Wooh, Review of Progress in $Q N D E$, ed. by D. O. Thompson and D. E. Chimenti, Plenum Press, New York, Vol. 13 A, 1994, pp. 469-476.

181."Ultrasonic Determination of Layer Orientation in Composite Laminates Using Adaptive Signal Classifiers," with I. N. Komsky and K. Zgonc, Review of Progress in $Q N D E$, ed. by D. O. Thompson and D. E. Chimenti, Plenum Press, New York, 1994, Vol. 13A, pp. 787-794.

182."Measurement of Processing Residual Stresses in Reaction Bonded Ceramics," with E. E. Gdoutos and H.-M. Hsiao, Proc. of 1994 SEM Spring Conf. on Exper. Mechanics, Baltimore, MD, June 1994, pp. 836-842.

183."Effect of Fiber Waviness on the Compressive Behavior of Thick Composites," with H.-M. Hsiao and S.-C. Wooh, Failure Mechanics in Advanced Polymeric Composites, ed. by G. A. Kardomateas and Y. D. S. Rajapakse, AMD-Vol. 196, ASME, International Mechanical Engineering Congress and Exposition, Chicago, IL, 1994, pp. 141-159.

184."Three-Dimensional Ultrasonic Imaging of Defects and Damage in Composite Materials," with S.-C. Wooh, Materials Evaluation, Vol. 52, No. 10, 1994, pp. 1199-1206.

185."Real-Time Monitoring of Damage Development in Crossply Composite Laminates by Means of Ultrasonic and Acoustic Emission Methods," with S.-C. Wooh and H.-J. Chun, Review of Progress in Quantitative Nondestructive Evaluation, ed. by D. O. Thompson and D. E. Chimenti, Plenum Press, New York, Vol. 14, 1995, pp. 1383-1390.

186."Failure Mechanisms and Damage Evolution in Crossply Ceramic-Matrix Composites," with G. Anastassopoulos, Int. J. Solids Struct., Vol. 32, No 3/4, 1995, pp. 341-355.

187."Residual Thermal Stressses in Filamentary SiC/Al Composite," with H.-J. Chun, Composites Engineering, Vol. 5, No. 4, 1995, pp. 425-436.

188."Determination of Interfacial Properties from Observations of Progressive Fiber Debonding and Pullout," with R. D. Cordes, Composites Engineering, Vol. 5, No. 6, 1995 pp. 633-648.

189."Wave Propagation in Composite Materials with Fiber Waviness," with S.-C. Wooh, Ultrasonics, Vol. 33, No. 1, 1995, pp. 3-10. 
190."Fabrication Methods for Unidirectional and Crossply Composites with Fiber Waviness," with H.-M. Hsiao and S.-C. Wooh, Journal of Advanced Materials, Vol. 26, No. 2, 1995, pp. 19-26.

191."A New Compression Test Method for Thick Composites," with H. M. Hsiao and S.-C. Wooh, J. of Composite Materials, Vol. 29, No. 13, 1995, pp. 1789-1806.

192."Acoustic Emission Study of Failure Mechanisms in Ceramic Matrix Composite under Longitudinal Tensile Loading," with J.-J. Luo and S.-C. Wooh, J. of Composite Materials, Vol. 29, No. 15, 1995, pp. 1946-1961.

193."Real-Time Ultrasonic and Acoustic Emission Monitoring of Damage in Graphite/Epoxy Laminates," with S.-C. Wooh and H. J. Chun, Composites Engineering, Vol. 5, No. 12, 1995, pp. 1403-1412.

194."Creep Characterization of a Metal-Matrix Composite under Transverse Loading," with H.-J. Chun, Proc. of 1995 SEM Spring Conf. on Exper. Mechanics, Grand Rapids, MI, June 12-14, 1995, pp. 279-283.

195. "Dynamic Response of Carbon/Epoxy Composites," with H. M. Hsiao and R. D. Cordes, High Strain Rate Effects on Polymer, Metal and Ceramic Matrix Composites and Other Advanced Materials, AD-Vol. 48, ed. by Y. D. S. Rajapakse and J. R. Vinson, ASME, New York, 1995, pp. 167-177.

196."Thermoelastoplastic Analysis of Filamentary Metal Matrix Composites," with H.J. Chun, Applied Composite Materials, Vol. 2, 1995, pp. 199-216.

197."Experimental Evaluation of Residual Stresses in Ceramics," with E. E. Gdoutos and H.-M. Hsiao, J. of the Mechanical Behaviour of Materials, Vol. 6, No. 1, 1995, pp. 21-30.

198. "Behavior of a Unidirectional Metal-Matrix Composite under Thermomechanical Loading," with H.-J. Chun, Journal of Engineering Materials and Technology, Vol. 118, No. 3, 1996, pp. 310-316.

199. "Size Effect and Fracture Characteristics of Composite Laminates," with Z. P. Bazant and Z. Li, J. of Engineering Materials and Technology, Vol. 118, No. 3, 1996, pp. 317-324.

200."Elastic Properties of Composites with Fiber Waviness," with H. M. Hsiao, Composites, Part A, Vol. 27A, No. 10, 1996, pp. 931-941.

201."Stress Analysis of Tire Sections," with T.-M. Wang and K. Huang, Tire Science and Technology, Vol. 24, No. 4, October-December, 1996, pp. 349-366.

202."Failure Mechanisms in Thick Composites under Compressive Loading," with H.M. Hsiao and S.-C. Wooh, Composites, Part B, Vol. 27B, No. 6, 1996, pp. 543-552.

203. "Nonlinear Elastic Behavior of Unidirectional Composites with Fiber Waviness under Compressive Loading," with H. M. Hsiao, J. of Engineering Materials and Technology, Vol. 118, No. 4, 1996, pp. 561-570. 
204. "Effect of Fiber Waviness on Stiffness and Strength Reduction of Unidirectional Composites under Compressive Loading," with H. M. Hsiao, Composites Science and Technology, Vol. 56, 1996, pp. 581-593.

205."Thermomechanical and Creep Characterization of Unidirectional SiC/A $l$ Composite," with H.-J. Chun, Journal of Advanced Materials, Vol. 27, No. 2, 1996, pp. 36-45.

206. "Development and Characterization of Brittle-Matrix Model Composites," with R. D. Cordes, Proc. of VIII International Congress of Experimental Mechanics, Soc. for Exper. Mech., 1996, pp. 316-323.

207. "Transverse Creep Behavior of a Unidirectional Metal Matrix Composite," with H.J. Chun, Mechanics of Materials, Vol. 25, 1997, pp. 37-46.

208. "Optical Methods for Characterization and Testing of Composite Materials," Proc. of SEM Spring Conf. on Exper. Mech., June 2-4, 1997, pp. 176-177.

209.“A Model Material System for Studying Brittle Matrix Composites,” with R. D. Cordes, Proc. of the 1997 SEM Spring Conf. on Exper. Mech., pp. 185-192.

210.“Acoustic Emission Monitoring of Fatigue Damage in Metals," with J.-J. Luo, C. G. Sifniotopoulos and H.-J. Chun, Review of Progress in Quantitative Nondestructive Evaluation, Vol. 16, ed. by D. O. Thompson and D. E. Chimenti, Plenum Press, New York, 1997, pp. 451-458.

211."Experimental Stress/Strain Analysis of Tread/Belt Area of Tires," Rubber and Plastics News, September 1997, pp. 166-178.

212."Effect of Fiber Waviness on High Strain Rate Behavior of Composites," with H. M. Hsiao, Proceedings of the Amer. Soc. of Composites, Twelfth Technical Conference, ed. by R. F. Gibson and G. M. Newaz, Dearborn, MI, Oct. 6-8, 1997, pp. 409-418.

213.“Acoustic Emission Monitoring of Fatigue Damage in Metals,” with J. J. Luo, C. G. Sifniotopoulos and H.-J. Chun, Nondestr. Test and Eval., 1998, Vol. 14, pp. 7187.

214. "Dynamic Compressive Behavior of Thick Composite Materials," with H. M. Hsiao and R. D. Cordes, Experimental Mechanics, 1998, Vol. 38, pp. 172-180.

215."Strain Rate Behavior of Comosite Materials," with H.-M. Hsiao, Composites, Part B, Vol. 29, No. 5, 1998, pp. 521-533.

216."Analysis of Acoustic Emission Output from Propagating Fatigue Crack," with C. G. Sifniotopoulos and J. J. Luo, Review of Progress in QNDE, Vol. 17A, ed. by Donald O. Thompson and Dale E. Chimenti, Plenum Press, New York, 1998, pp. 579-586. 
217. "Acousto-Ultrasonic Techniques for Evaluation of Bond Integrity of Composite Repair Patches," Review of Progress in QNDE, Vol. 17A, ed. by Donald O. Thompson and Dale E. Chimenti, Plenum Press, New York, 1998, pp. 1331-1338.

218. "An Experimental Study of Residual Stresses and Transverse Strain Reversal of Unidirectional Ceramic Composites at Elevated Temperature," with J. J. Luo, Proc. of SEM Spring Conf. on Exper. Mech., June 1-3, 1998, pp. 75-77.

219."Experimentation and Modeling of Composite Materials," Experimental Mechanics, Vol. 39, No. 1, March 1999, pp. 1-19.

220."Intelligent RTM Processing," with J. M. Fildes, Proc. of Conference on On-Line Sensing and Control for Liquid Molding of Composite Structures, Annapolis, MD, April 14-15, 1999.

221."Nonlinear Behavior of Thick Composite Materials with Fiber Waviness," with H. J. Chun, and J.-Y. Shin, Proc. of $40^{\text {th }}$ AIAA/ASME/ASCE/AHS/ASC Structures, Structural Dynamics and Materials Conference, St. Louis, MO, April 12-15, 1999, (Paper No. AIAA-99-1245).

222."Intelligent RTM Processing of Composites," with J. M. Fildes, Proc. of SAMPE '99, Long Beach, CA, May 23-27, 1999.

223."Mechanical Properties and Failure Behavior of Cord/Rubber Composite," with S. Rao and D. McFarlane, Proc. of 1999 SEM Spring Conference on Experimental Mechanics, Soc. for Exper. Mech., 1999, pp. 821-824.

224."Is There a Thickness Effect on Compressive Strength of Unnotched Composite Laminates?" with H. M. Hsiao, International Journal of Fracture, Vol. 95, 1999, pp. 143-158.

225."Size Effect on Compression Strength of Fiber Composites Failing by Kink Band Propagation," with Z. P. Bazant, J. J. H. Kim, E. Becq-Giraudon and G. Zi, International Journal of Fracture, Vol. 95, 1999, pp. 103-141.

226."Predictions of Nonlinear Elastic Behavior of Thick Composites with Fiber Waviness under Tensile and Compressive Loadings Using a FEA Model," with H.J. Chun and S. W. Lee, Proc. of $6^{\text {th }}$ International Conference on Composites Engineering, ICCE/6, Orlando, FL, June 27-July 3, 1999.

227."Testing and Analysis of Composite Sandwich Beams," with J. L. Abot and K. A. Wang, Proc. of $12^{\text {th }}$ Intern. Conference on Composite Materials, ICCM12, Paris, France, July 5-9, 1999.

228."Effects of Strain Rate and Fiber Waviness on the Compressive Behavior of Composite Laminates," with H. M. Hsiao, Proc. of $12^{\text {th }}$ Intern. Conference on Composite Materials, ICCM12, Paris, France, July 5-9, 1999.

229."Physical Aging and Creep Characterization of Carbon/Polyimide Composite," with J. J. Luo and Z. Sun, Proc. of $12^{\text {th }}$ Intern. Conference on Composite Materials, ICCM12, Paris, France, July 5-9, 1999. 
230."Strain Rate Effects on the Transverse Compressive and Shear Behavior of Unidirectional Composites," with H.-M. Hsiao and R. D. Cordes, Journal of Comp. Materials, Vol. 33, No. 17, 1999, pp. 1620-1642.

231. "Simplified Interlaminar Shear-Stress Analysis of Cracked Crossply Composite Laminates," with C. L. Tsai, Proc. of the $14^{\text {th }}$ Technical Conf., Amer. Soc. for Composites, September 1999, Dayton, OH.

232."Fatigue and Fracture Behavior of a Steel Cord/Rubber Composite," with S. Rao, Proc. $12^{\text {th }}$ ASC Conf., Sept. 27-29, 1999, Dayton, OH.

233."Effect of Fiber Waviness on the High-Strain Rate Behavior of Composites," with H. M. Hsiao, J. of Thermoplastic Composite Materials, Vol. 12, September 1999, pp. 412-422.

234."Crack Detection in Formed Sheet Metal by Acoustic Emission," with C. G. Sifniotopoulos, E. Widder and G. Novak, Materials Evaluation, Vol. 57, No. 10, Oct. 1999, pp. 1095-1098.

235. "Application of Acousto-Ultrasonic Technique in Evaluation of Bond Strength and Adhesive Degradation in Composite Repair Patch," $31^{\text {st }}$ International SAMPE Technical Conference, Oct. 26-30, 1999, Chicago, IL.

236."Analysis of Nonlinear Flexural Behavior of Thick Composites with Fiber Waviness," with H. J. Chun and S. W. Lee, Proc. of ASME IMECE '99, Thick Composites for Load Bearing Structures, Nov. 14-19, 1999, Nashville, TN.

237."Determination of Shear Modulus of Single Fibers," with C.-L. Tsai, Exper. Mech., Vol. 39, No. 4, Dec. 1999, pp. 284-286.

238."Nonlinear and Dynamic Compressive Behavior of Composites with Fiber Waviness," with H.-M. Hsiao, Time Dependent and Nonlinear Effects in Polymers and Composites, ed. by Richard A. Schapery and C. T. Sun, ASTM STP 1357, Amer. Soc. for Testing and Materials, West Conshohocken, PA, 1999, pp. 223-237.

239. "Permeability and Resin Flow Measurements and Simulations in Composite Preforms," with M. K. Um, B. W. Childs and D. H. Kim, Proc. of $45^{\text {th }}$ International SAMPE Symposium, May 21-25, 2000, pp. 761-775.

240."A New Kinetic Model for Degree of Cure and Viscosity in Liquid Molding Applications," with M. K. Um, Proc. of $45^{\text {th }}$ International SAMPE Symposium, May 21-25, 2000, pp. 1598-1610.

241."Determination of Relaxation Modulus of Polymers and Composites," with Y. K. Kim, Proc. of $45^{\text {th }}$ International SAMPE Symposium, May 21-25, 2000, pp. 16131626.

242. "Analysis of Acoustic Emission Waveforms from Propagating Fatigue Crack," with J. Choi and J. J. Luo, Review of Progress in QNDE, ed. by D. O. Thompson and D. E. Chimenti, American Institute of Physics, Melville, NY, Vol. 19A, 2000, pp. 351358. 
243. "Failure Mechanisms of Unidirectional Composites under Dynamic Loading," with S. Rao, SEM 2000, Proc. of IX International Congress on Experimental Mechanics, June 5-8, 2000, pp. 195-197.

244. "Pulse Loading Method for Viscoelastic Characterization of Aging Composite Materials," with J. J. Luo, SEM 2000, Proc. of IX International Congress on Experimental Mechanics, June 5-8, 2000, pp. 397-400.

245."Nonlinear Behavior of Composite Sandwich Beams in Three-Point Bending," with E. E. Gdoutos, K.-A. Wang and J. L. Abot," Proc. of IX Intern. Congress on Exper. Mech., June 2000, pp. 155-158; also in Exper. Mech., Vol. 41, 2001, pp. 182-188.

246."Nonlinear Analysis of Curved Composite Beams with Fiber Waviness," with H.-J. Chun and S. W. Lee, Proc. of Seventh Annual International Conference on Comp. Eng. (ICCE/7), July 2-8, 2000, Denver, CO.

247. "A New Technique to Determine In-Plane Permeability of Fiber Preforms: Gas Flow Method," with M. K. Um and B. S. Hwang, ACCM-2000, 2 $2^{\text {nd }}$ AsianAustralasian Conference on Composite Materials, Kyongju, Korea, 18-20 August, 2000.

248."Nonlinear Behavior of Thick Composites with Uniform Fiber Waviness," with H.J. Chun and J.-Y. Shin, AIAA J., Vol. 38, No. 10, Oct. 2000, pp. 1949-1955.

249."Fabrication Testing and Analysis of Composite Sandwich Beams," with J. L. Abot, Comp. Scie. and Tech., Vol. 60, No. 12-13, 2000, pp. 2455-2463.

250."Dynamic Mechanical Properties and Failure Mechanisms of PVC Foams," with S. Rao, Dynamic Failure in Composite Materials and Structures, AMD-Vol. 243, The 2000 ASME Congress and Exposition, pp. 37-48.

251."Nonlinearities in the Load-Deflection Behavior of Composite Sandwich Beams," with E. E. Gdoutos, Recent Advances in Applied Mechanics - Honorary Volume for Professor A. N. Kounadis, National Technical University of Athens, edited by J. T. Katsikadellis, D. Beskos and E. E. Gdoutos, 2000, pp. 22-30.

252."A Cylinder Model for Characterization of Deformation and Damage Development in a Unidirectional Composite," with J.-J. Luo, Comp. Scie. and Tech., Vol. 60, No. 15, November 2000, pp. 2791-2802.

253. "Multiaxial Characterization and Modelling of a PVC Cellular Foam," with E. E. Gdoutos and K.-A. Wang, Proc. of $15^{\text {th }}$ Tech. Conf. of the Amer. Soc. for Composites, Texas A\&M University, September 24-27, 2000; Journal of Thermoplastic Composite Materials, Vol. 14, 2001, pp. 365-373.

254. "Distributed Photoacoustic System for Cure Monitoring of Composites," with P. A. Fomitchov, Y. K. Kim, A. K. Kromine, S. Krishnaswamy and J. D. Achenbach, Proc. SPIE, Advanced Nondestructive Evaluation for Structural and Biological Health Monitoring, Vol. 4335, 2001, pp. 323-329. 
255."A Gas Flow Method for Determination of In-plane Permeability of Fiber Preforms," with M.-K. Um and B. W. Childs, Polymer Composites, Vol. 22, No. 1, Feb. 2001, pp. 47-56.

256."Effects of Material and Geometric Nonlinearities on the Tensile and Compressive Behavior of Composite Materials with Fiber Waviness, with H.-J. Chun and J.-Y. Shin, Comp. Scie. and Tech., Vol. 61, No. 1, 2001, pp. 125-134.

257. "Fatigue and Fracture Behavior of a Steel Cord/Rubber Composite," with S. Rao and D. McFarlane, Journal of Thermoplastic Composite Materials, Vol 14, May 2001, pp. 213-224.

258."Deformation of Inhomogeneous Elastic Solids with Two-Dimensional Damage," with J.-J. Luo, J. Appl. Mech., Vol. 68, July 2001, pp. 528-536.

259."Laser Ultrasonic Enabled "Smart" Mold for Composite Parts Manufacturing," with P. A. Fomichov, Y. K. Kim, A. K. Kromine and J. D. Achenbach, Review of Progress in QNDE, Amer. Inst. of Physics, Melville, NY, Vol. 20, 2001 pp. 18021807.

260. "Composite Sandwich Beams under Low Velocity Impact," with J. L. Abot, Proc. of $42^{\text {nd }}$ AIAA SDM Conf., Seattle, WA, April 2001.

261."Indentation Failure in Composite Sandwich Structures," with E. E. Gdoutos and K. A. Wang, Proc. of the 2001 SEM Annual Conf., June 4-6, 2001, Portland, OR, 2001, pp. 528-531.

262."Failure of Composite Sandwich Beams," with E. E. Gdoutos and K.-A. Wang, Proc. of Second Greek National Conf. on Composite Materials, HELLAS-COMP 2001, Patras, Greece, June 6-9, 2001.

263."The Role of Clays on the Mechanical Properties of Epoxy Matrix Nanocomposites," with H. Miyagawa, Proc. of $38^{\text {th }}$ Annual Meeting of the Clay Minerals Soc., Madison, WI, June 2001.

264."Indentation Failure of Sandwich Panels," with E. E. Gdoutos and K.-A. Wang, Proc. of $6^{\text {th }}$ Greek National Congress on Mechanics, ed. by E. C. Aifantis and A. N. Kounadis, Thessaloniki, Greece, July 19-21, 2001, pp. 320-326.

265."TEM Sample Preparation of Polymer Based Nanocomposites Using Focused Ion Beam Technique," with H. Miyagawa and W.-A. Chou, Proc. of Microscopy and Microanalysis 2001 Meeting, Long Beach, CA, Aug. 2001.

266. "Multiaxial Characterization and Modelling of a PVC Cellular Foam," with E. E. Gdoutos and K.-A. Wang, J. of Thermoplastic Composites, Vol. 14, No. 5, 2001, pp. 365-373.

267. "Core Failure Modes in Composite Sandwich Beams," with E. E. Gdoutos, J. L. Abot and K.-A. Wang, ASME, 2001, IMECE, AD.-Vol. 65/AMD-Vol. 249, 2001, pp. 293-303. 
268."Effect of Loading Conditions on Deformation and Failure of Composite Sandwich Beams," with E. E. Gdoutos, J. L. Abot and K.-A. Wang, ASME, IMECE 2001/AMD-25412, 2001.

269."Size Effect in Fracture of Sandwich Structure Components: Foam and Laminate," with A. P. Bazant, Y. Zhou,and D. Novak, ASME, IMECE 2001/AMD-25413.

270."Impact Behavior of Sandwich Beams with Various Composite Facesheets and Balsa Wood Core," with J. L. Abot and A. Yasmin, ASME, IMECE 2001/AMD25405.

271."Failure of Cellular Foams under Multiaxial Loading," with E. E. Gdoutos and K.A. Wang, Composites, Part A, Vol. 33, 2002, pp. 163-176.

272. "Contact Law for Composite Sandwich Beams," with J. L. Abot and E. E. Gdoutos, J. of Sandwich Structures and Materials, in press, 2002.

273."Microplane Model for Stiff Foams and Finite Element Analysis of Sandwich Failure by Core Indentation," with M. Brocca and Z. P. Bazant, Int. J. of Solids and Structures, in press, 2002.

274. "A Study of Cure Kinetics by the Use of Dynamic Differential Scanning Calorimetry," with M.-K. Um and B.-S. Hwang, Composites Science and Technology, Vol. 62, 2002, pp. 29-40.

275. "Determination of Critical Tearing Energy of Tire Rubber," with E. E. Gdoutos and P. Schubel, Proc. 2002 SEM Spring Conf. on Exper. Mechanics, June 10-12, 2002, Milwaukee, WI.

276. "Processing and Characterization of Epoxy/Clay Nanocomposites," with H. Miyagawa, E. E. Gdoutos and J. J. Luo, Proc. 2002 SEM Spring Conf. on Exper. Mech., June 10-12, 2002, Milwaukee, WI.

277. "Cure Cycle Effect on Composite Structures Manufactured by Resin Transfer Molding,” with Y. K. Kim, J. Composite Materials, Vol. 35, 2002.

278. "Compression Facing Wrinkling of Composite Sandwich Structures," with E. E. Gdoutos, K.-A. Wang and J. L. Abot, Mech. of Materials, in press, 2002.

279."Failure Modes of Composite Sandwich Beams," with E. E. Gdoutos, K.-A. Wang and J. L. Abot, International Journal of Damage Mechanics, in press, 2002. 


\section{List of Contributors}

Abot, J. L., 55

Abrate, S., 661

Abu-Alrub, R. K., 109

Achenbach, J. D., 367

Al-Khalil, M., 671

Allen, D. H., 235

Andresen, K., 325

Azeloglu, E. U., 353

Babatsouli, E., 389

Baczmanski, A., 477

Bakis, C.E., 315

Banks-Sills, L., 225

Barkoula, N.-M., 175

Barrallier, L., 487

Barthelat, F., 75

Bazant, Z., 13

Bechel, V. T., 163

Biancaniello, F. S., 507

Birch, R. S., 671

Bosia, F., 303

Botsis, J., 303

Braham, C., 477

Buslaps, T., 527

Buyny, R. A., 689

Camping, J. D., 43

Cardon, A. H., 551

Carlsson, L. A., 683

Carrado, A. 487

Casas, J.R., 715

Chamis, C. C., 631

Chao, Y. J., 245

Chen, T. Y., 345

Chern, S. M., 701

Chiang, F. P., 353

Chou, Y. C., 345

Chun, H.-J., 433

Coker, D., 275

Daymond, M. R., 495

De Visscher, J., 551

De Wilde, W. P., 551, 595

Deng, X., 217

Dinescu, D., 551
Doyle, J. F., 585

Emerson, R. P., 315

Emri, I., 19

Espinosa, H., 75

Facchini, M., 303

Feiereisen, J.-P., 527

Ferry, O., 527

Fromme, P., 421

Galea, S., 737

Gaudette, G. R., 353

Gdoutos, E. E., 55

Giannis, S., 175

Gmür, Th., 303

Gnäupel-Herold, T., 507

Guo, Z., 367

Guralnick, S. A., 187

Haldeman, B. J., 315

He, K.Y., 619

Hoes, K., 551

Hsiao, H. M., 689

Hung, M. Y. Y., 397

Isaacs, J., 3

Jackson, J. H., 561

Jacques, A., 527

Jones, R., 737

Jones, R. M., 537

Karalekas, D. E., 749

Kardomateas, G. A., 645

Karger-Kocsis, J., 175

Keene, L., 353

Kim, R. Y., 163

Kobayashi, A. S., 561

Korsunsky, A. M., 495

Krukenkamp, I. B., 353

La Saponara, V., 645

Lawler, J. S., 335

Lee, H. L., 345

Lee, J., 153

Lee, S. M., 689

Levy-Tubiana, R., 477 
Li, Q. M., 671

Librescu, L., 609

Liu, C. T., 257

Lodini, A., 477, 487

Lukas, P., 457

Malukhin, K., 75

Marzocca, P., 609

McKenzie, I. H., 737

Mikula, P., 457

Mines, R. A. W., 671

Minnetyan, L., 631

Mohammadi, J., 187

Morgan, D., 769

Nemat-Nasser, S., 3

Nardiello, J., 757

O'Brien, E. W., 727

Ohms, C., 467, 515

Ortiz, M., 275

Pandolfi, A., 275

Papanicolaou, G. C., 175

Papazian, J. M., 757

Parameswaran, V., 769

Pastor, M., 87

Pindera, J. T., 571

Pitt, S., 737

Post, D., 291

Prask, H., J., 507

Priesmeyer, H. G., 495

Prodan, T., 19

Pyzalla, A., 527

Ravichandran, G., 31

Reetz, B., 527

Reifsnider, K., 87

Rigby, R., 671

Rittel, D., 267

Rodopoulos, C. A., 197

Rohrs, H., 65

Rome, J., 3

Rosakis, A. J., 275

Rowlands, R. E., 619

Roy, A. K., 43

Ruoff, R. S., 65

Saka, M., 443
Samoilis, G., 175

Sandhu, J. S., 381

Sayir, M. B., 421

Schwartz, J., 225

Schwarz, R. C., 757

Sciammarella, C. A., 121

Sciammarella, F. M., 121

Shah, S. P., 335

Shukla, A., 769

Silva, W. A., 609

Simitses, G. J., 645

Smith, C. W., 209

Sol, H., 551, 595

Sotiropoulos, D. A., 389

Soutis, C., 153

Sprauel, J.-M., 487

Srivastava, V., 769

Sutton, M. A., 217

Tandon, G. P., 163

Tanner, A., 671

Todaro, J., 353

Tohmyoh, H., 443

Tsai, C.-L., 133, 145

Tsai, Y.-S., 145

Tsao, S. H., 345

Tuttle, M.E., 701

Venson, A. R., 109

Vinson, J. R., 99

Voyiadjis, G. Z., 109

Vrana, M., 457

Vural, M., 31

Wagner, V., 457

Wang, H., 381

Webster, G. A., 467

Wierzbanowski, K., 477

Williams, J. J., 235

Wimpory, R. C., 467

Wooh, S.-C., 133, 409

Xiao, S., 99

Yates, J. R., 197

Youtsos, A. G., 467, 515

Yu, C., 275

Yu, M.-F., 65

Zuo, J., 217 